\title{
Teardrops at the Lake: Chemistry of New Kingdom to Makuria Glass Beads and Pendants Between the First and Second Nile Cataracts
}

\author{
Joanna Then-Obłuska (iD) Laure Dussubieux
}

Accepted: 10 October 2021

(C) The Author(s) 2021

\begin{abstract}
International expeditions extensively excavated Lower Nubia (between the First and Second Nile Cataracts) before it was submerged under the waters of Lake Nasser and Lake Nubia. The expeditions concentrated on monumental architecture and cemeteries, including sites at Qustul and Serra East, where the New Kingdom, and Napatan, Meroitic, Nobadian, and Makurian-period elites and common people were buried, ca. 1400 BC-AD 1400. Although the finds abound in adornments, including bead imports from Egypt and South India/Sri Lanka, only a few traces of local glass bead-making have been recorded in Nubia so far. Based on results of laser ablation-inductively coupled plasma-mass spectrometry (LA-ICP-MS) analysis of 76 glass beads, pendants, and chunks from Qustul and Serra East contexts, dated between the New Kingdom and the Makuria Kingdom periods, this paper discusses the
\end{abstract}

Supplementary Information The online version contains supplementary material available at https://doi. org/10.1007/s10437-021-09467-1.

J. Then-Obłuska $(\bowtie)$

Antiquity of Southeastern Europe Research Centre, University of Warsaw, Krakowskie Przedmieście 32, 00-927 Warsaw, Poland

e-mail: j.then-obluska@uw.edu.pl

L. Dussubieux

Elemental Analysis Facility, Field Museum, 1400 S. Lake

Shore Dr, Chicago, IL 60605, USA

e-mail: ldussubieux@ fieldmuseum.org composition and provenance of two types of plant-ash soda-lime ( $\mathrm{v}-\mathrm{Na}-\mathrm{Ca})$ glass, two types of mineral sodalime glass ( $\mathrm{m}-\mathrm{Na}-\mathrm{Ca}$ ), and two types of mineral-sodahigh alumina (m-Na-Al) glass. It also presents the remains of a probable local glass bead-making workshop dated to the period of intensive long-distance bead trade in Northeast Africa, AD 400-600.

Résumé La Basse Nubie (région située entre la Première et la Deuxième Cataracte du Nil) a fait l'objet de fouilles extensives par des missions internationales, avant d'être submergée par les eaux du lac Nasser et du lac de Nubie. Les expéditions ont concentré leurs efforts sur l'architecture monumentale et les nécropoles, incluant des sites comme Qustul et Serra Est, où étaient enterrés les élites et les gens ordinaires pendant près d'un millénaire. En effet, les sépultures de ces cimetières datent du Nouvel Empire, ainsi que des périodes Napatéenne, Méroïtique, Nobadienne et Makurite (14 ${ }^{\mathrm{e}}$ s. av. J.-C. $-14^{\mathrm{e}}$ s. ap. J.-C.). Bien que les trouvailles archéologiques d'ornements personnels soient nombreuses, y compris des perles importées d'Egypte et du Sud de l'Inde/Sri Lanka, les traces d'une manufacture locale du verre en Nubie restent rares. En se basant sur les résultats d'analyse obtenus par spectrométrie de masse à plasma inductif avec prélèvement par ablation laser (LA-ICP-MS) de 76 perles, pendentifs et morceaux de verre de Qustul et Serra Est, cet article discute la composition et la provenance des types de verre, datés entre l'époque du Nouvel Empire et la période du royaume de Makuria. 
$\mathrm{Au}$ total deux types de verre sodo-calcique à base de cendres végétales ( $\mathrm{v}-\mathrm{Na}-\mathrm{Ca}$ ), deux types de verre sodocalcique à la soude minérale (m-Na-Ca) et deux types de verre à la soude minérale et à fortes teneurs en alumine (m-Na-Al) ont été identifiés. L'article présente également les restes d'un probable atelier de perles en verre actif durant une période pendant laquelle ce type d'ornements étaient l'objet d'un intense commerce à longue distance en Afrique du Nord-Est $\left(4^{\mathrm{e}}-6^{\mathrm{e}}\right.$ s. ap. J.-C.).

Keywords Glass beads - Elemental composition · LA-ICP-MS · Bead-making · Lower Nubia $\cdot$ Indian Ocean trade

\section{Introduction}

This article offers an overview of glass types in Lower Nubia, their provenance, and chronology based on the laser ablation-inductively coupled plasma-mass spectrometry (LA-ICP-MS) analysis of the New Kingdom through Medieval glass beads and pendants from Qustul and Serra East cemeteries, and the glass remains (beads, pendants, and chunks) from a Nobadian Serra East household. Historic Nubia encompasses the southern edge of modern Egypt and the northern part of modern Sudan (Dafalla, 1975; Osman, 1992; Taha, 2013, 2021). Due to the natural boundary of the rock-strewn rapids of the Second Cataract, Nubia is usually referred to as comprising two parts-Lower Nubia, between the First and the Second Nile Cataracts, and Upper Nubia, in the south (Fig. 1). As a part of the Nubian civilization, Lower Nubia witnessed one of the earliest events of social complexity in Africa. Thanks to its frontier location, it also benefited from contacts with its Egyptian neighbors. Archaeological finds suggest that the A-Group people (3700-2800 BC) and the C-Group people (2300-1550 BC) were wealthy individuals. Due to the strategic location at the junction of trade routes, these individuals controlled the trade routes and provided Egypt and the Mediterranean with raw materials and exotics. The Pan Grave people (2200-1550 BC), represented by small and dispersed populations from the Eastern Desert, also contributed to the rich history of the Lower Nubian region (e.g., Adams, 1977; Hafsaas,
2006; Török, 2008; Williams, 1983, 1986, 1989, 1993).

The region was under Egyptian control in the New Kingdom (ca. 1570-1069 BC). Between 747 and $656 \mathrm{BC}$, the 25th Dynasty, otherwise called Kushite Dynasty, which originated in Lower Nubia, controlled Ancient Egypt and other parts of northeast Africa, stretching from the confluence of the Niles to the Mediterranean. The Nubian kings promoted the revival of the arts, language, architecture, and religion of the New Kingdom, and Egyptian artisans and scribes were employed in Nubia (e.g., Fisher, 2012; Török, 2008; Welsby, 1996; Williams, 1990). The wealth of the Lower Nubian region during the Napatan period (ca. 750-350 $\mathrm{BC}$ ) is assumed to have continued when the center of power moved to the kingdom of Meroë (ca. 350 $\mathrm{BC}-\mathrm{AD}$ 350). Under Roman rule in the north and Meroë in the south, in the first through fourth centuries $\mathrm{AD}$ (Classic and Late Meroitic period), Lower Nubia was an intermediary between Upper Nubia and Egypt (e.g., Török, 2008; Williams, 1991). During the Kingdom of Nobadia (ca. AD 350-600), the region had unsettled relations with the Blemmyes, active in the Eastern Desert and the Red Sea ports, and the Egyptians in the north (Emery \& Kirwan, 1938; Obłuski, 2013, 2014). By the early eighth century AD, Nobadia and Makuria (in Upper Nubia) were united under a Makurian king, which gave rise to the Makurian period (seventh-fourteenth centuries AD) (Fisher, 2012; Welsby, 2002).

In the sixth century AD, Lower Nubia adopted Christianity, and by the seventh century, there were changes in burial practices, especially in the number of burial goods. In contrast to the pre-Christian burials that abounded in grave goods, these were scarce or absent altogether in Christian burials. Before the Christian era, many beads were buried with deceased Nubians regardless of their social status, sex, and age. These included locally available ostrich eggshell and semi-precious stones and imported resources (Red Sea marine mollusk shells, Mediterranean Corallium rubrum sp., semiprecious stone). The beads were mostly made of faience and glass (Then-Obłuska, 2018b). Despite their apparent profusion in Nobadian graves, only one that assumed glass bead-making workshop has been recorded in a house at Serra East, in Lower Nubia (Williams, 1993, p. 229-230). Hence, the 


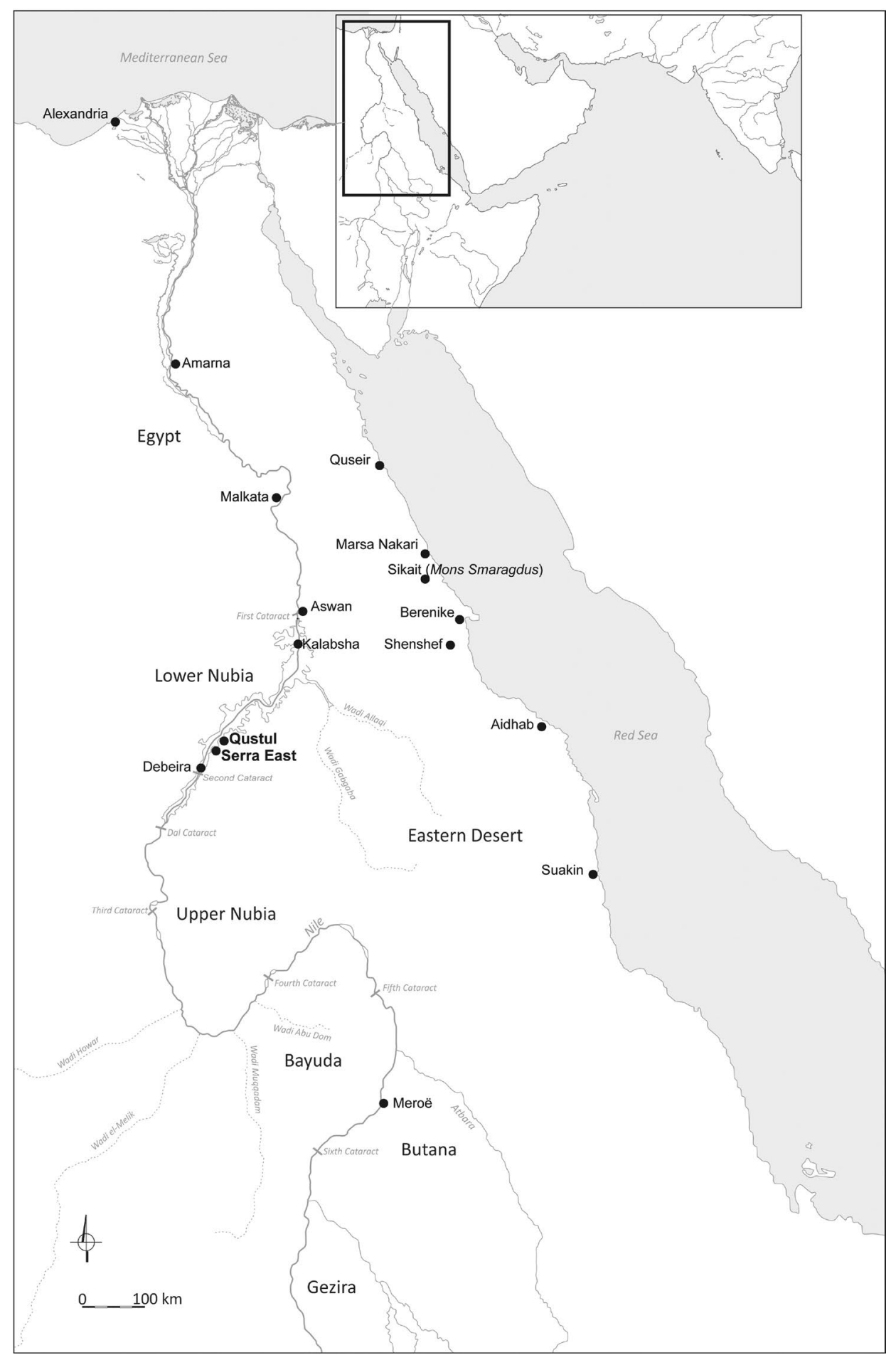

Fig. 1 Location of sites mentioned in the text (by Szymon Maślak and Joanna Then-Obłuska) 
beads seem to testify to a rich history of wide-ranging contacts in the region. While Nubia's trade links with Egypt and the Mediterranean have long been well acknowledged, its eastern connections have only recently been recognized. Lower Nubia was close to Berenike, Marsa Nakari, and Quseir ports at the Red Sea, part of a busy commercial network connecting the Mediterranean world with the Indian Ocean during the Roman and Early Byzantine periods. The glass bead finds in Lower Nubia dating to these periods testify to the contacts with these ports and the Nubian Nile Valley (Then-Obłuska \& Dussubieux, 2016; Then-Obłuska \& Wagner, 2019a, b; Then-Obłuska, 2015a, 2019).

\section{Lower Nubian sites and samples}

Before disappearing under the waters of what is now Lake Nasser and Lake Nubia in the 1960s, Lower Nubia was the focus of extensive excavations that yielded, among others, a wide variety of beads, including glass ones. These beads were stored in museums and institutions around the world. One of the archaeological rescue missions was the Oriental Institute Nubian Expedition (OINE) of the University of Chicago (e.g., Williams, 2009; Williams \& Heidorn, 2019). An assemblage of eighty-one beads and artifacts from Qustul and Serra East found during the OINE excavations in the early 1960s, and presently stored in the Oriental Institute Museum University of Chicago, was used in this study. Of this number, one bead (OINE67) appears to be a modern intrusion, three were made of stone (OINE19, 27, 51), and one was too corroded (OINE21). Hence, five beads were excluded from the LA-ICP-MS analysis.

The sites in Qustul and Serra East were excavated on the east bank of the Nile, just to the north of the Second Cataract (Williams, 1990, 1991, 1992, 1993). The samples were found mostly in graves, at cemeteries Q, QC, R, VF, W in Qustul (OINE01-18, 20-26, 28-50, 52-66), as well as at cemetery B (OINE79) and its surface (OINE68-69) in Serra East. There are also glass beads from a household context in Serra East, site LB. This context is interpreted as a bead workshop associated with Nobadian culture (OINE70-78, 80-81). The Nobadian cemeteries are generally tumuli superstructures with either single or multiple grave units. Various artifacts (metal tools, weapons, toilet utensils, and fittings, as well as some stone, clay, bone, and ivory objects, basketry, textiles, and glass vessels) have been found, although pottery and bead adornments dominate the grave assemblages. Bead adornments were discovered mostly loose, scattered, and in heaps. They accompanied the deceased regardless of their age or sex. Necklaces and bracelets are the main beadwork types; however, other forms have also been recorded (Williams, 1991, 1993).

Site LB was a house in a shallow wadi built against the south side of a rock outcrop on drift sand. The structure was built into the natural squarish inset or break in the rock face. Stones were loosely stacked with mud to form walls for one room with a rough stone floor paving. The walls stood only about $0.5 \mathrm{~m}$ high (Williams, 1993, pp. 229-230). The house or shelter, $2.7 \times 3.7 \mathrm{~m}$, contained a good collection of whole and smashed but complete pottery vessels. Disturbed skeletons of two goats or sheep in clean sand were found beneath the paving and deep debris. Outside, to the east, against the rock, several cooking or hearth constructions, with considerable ash deposits, were found. The doorway may have been in the east wall. Further to the west, $3.05 \mathrm{~m}$ northwest of the shelter, a fragmentary oven or kiln was also found built into a small corner against the rock. To the south, test pits in the wadi sand yielded occasional bead and pendant fragments (OINE70-75, 78, 80, 81), partially perforated stone beads, and some flint chipping debris and potsherds. Glass chunks (OINE76-77), ostrich eggshell fragments, unfinished ostrich eggshell beads, and a carnelian chunk were also collected from site LB. All of these suggest that there was a bead-making workshop at the site. The hearth was approximately $2.30 \mathrm{~m}$ deep and $2 \mathrm{~m}$ wide and consisted of upright stones with possible ash deposits. While the Qustul cemetery Q (220) was dated to ca. AD 370/380-410 (OINE01-42), the remaining cemetery sites were dated between the early fifth and sixth centuries AD (OINE43-66) (Williams, 1991, 1993). The reuse of Meroitic beads in Nobadian graves was a common practice, and these are treated as Meroitic-dated bead types. Other beads (OINE58-61, 63-64) were of the 25th Dynasty date (Williams, 1990, and personal communication). A few samples belong to the New Kingdom (OINE62, 65) and Makurian (OINE57, 73) dates. 
The glass assemblage for this study was selected to include all types of manufacturing techniques, color, and shape. Electronic Supplemental Material (ESM 1) presents the specimens arranged based on their Oriental Institute Museum (OIM) number, including information on the site, find context, find number, and all registered data about the techniques of manufacture, shape, color, and dimensions (mm scale). The assemblage includes monochrome, bichrome, and mosaic glass beads, as well as metal-in-glass beads with gold or silver foil between two glass layers. A variety of manufacturing techniques (e.g., drawing a glass tube; winding glass around a metal mandrel; folding a glass strip around a metal mandrel or joining glass strips around a mandrel; and rod-piercing glass), finishing processes (segmenting in molds and breaking apart the segments of a drawn tube; or cutting a drawn glass tube and heat-rounding the sections), and decoration (the application of trails, mosaic eyes) are recognized in the assemblage. The objects are illustrated in Fig. 2 and identified by their sample numbers.

\section{Results and discussion}

The compositions of the glass beads, including 56 major, minor, and trace elements, were obtained using LA-ICP-MS at the Elemental Analysis Facility at the Field Museum. More details on the instrumentation
Fig. 2 A-C Glass bead samples according to OINE number (not to scale, photo and photo processing by $\mathrm{J}$. Then-Obłuska)

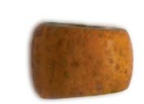

OINE 1

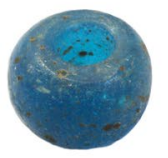

OINE 6

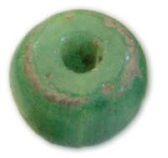

OINE 11

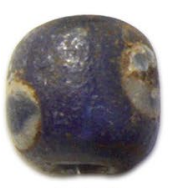

OINE 16

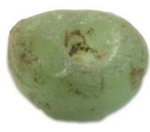

OINE 23

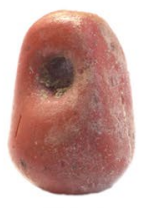

OINE 29
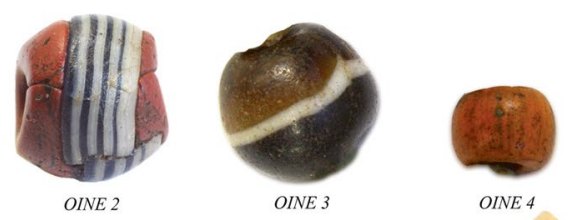

OINE 4

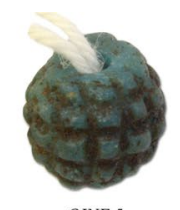

OINE 5

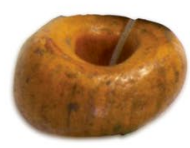

OINE 7

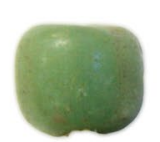

OINE 8

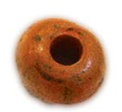

OINE 12

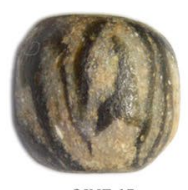

OINE 17

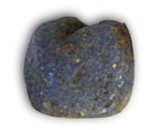

OINE 13

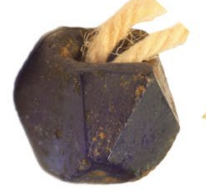

OINE 9

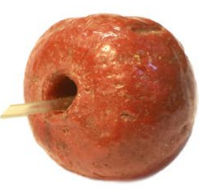

OINE 10
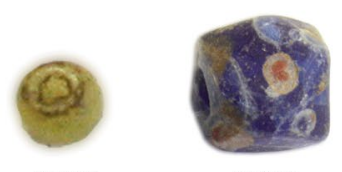

OINE 14

OINE 15
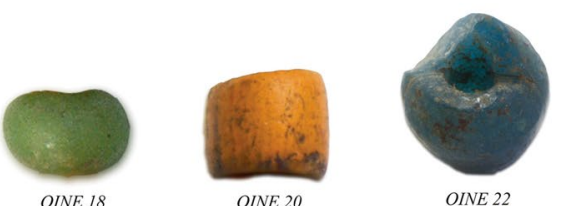

OINE 22
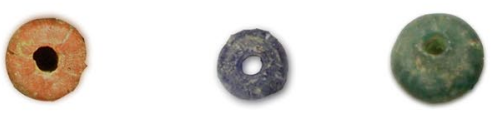

OINE 26

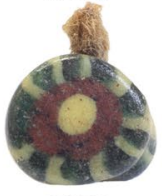

OINE 28

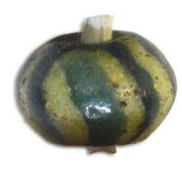

OINE 30

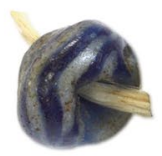

OINE 31

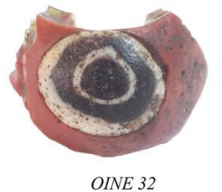


Fig. 2 (continued)

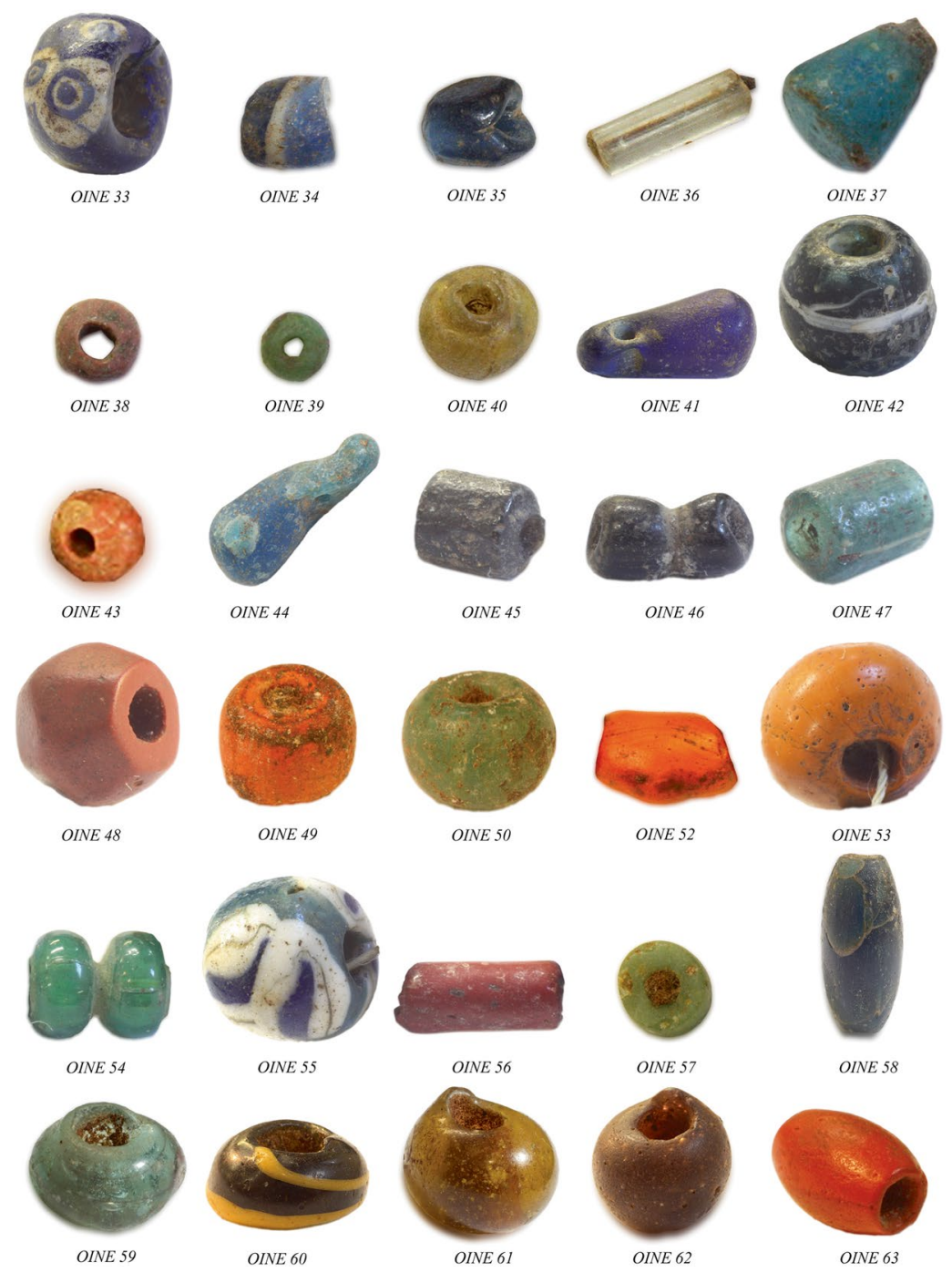

and protocol are in Then-Obłuska and Dussubieux (2021), and ESM 2 presents major, minor, and trace element compositions of Corning Reference Glass B and D. Seventy-six glass beads, pendants, and chunks were analyzed. Different colors of the bichrome and polychrome beads were measured individually, and some measurements had to be repeated because, in some cases, the color meant to be targeted had been missed, and another one was measured instead. These resulted in 112 compositions (ESM 3). Soda is the main alkali in all glass samples, and four main glass types were identified based on the content of $\mathrm{MgO}$ and $\mathrm{Al}_{2} \mathrm{O}_{3}$ (Fig. 3). Soda-lime glasses form the most numerous group with eight samples made of plant ash-soda-lime glass (v-Na-Ca) and 84 samples made

of a mineral soda-lime glass (m-Na-Ca). Four samples feature mineral- or plant ash-soda composition $(\mathrm{m} / \mathrm{v}-\mathrm{Na}-\mathrm{Ca})$, and 16 samples are mineral soda-high alumina (m-Na-Al) (Table 1).

v-Na-Ca glass

Eight samples made from soda-rich glass have low alumina $\left(\mathrm{Al}_{2} \mathrm{O}_{3}<2 \%\right)$ and high magnesia $(\mathrm{MgO}>3 \%)$ concentrations, indicating the use of plant-ash soda as a flux. Lime $(\mathrm{CaO})$ concentrations range 3.5-8.0\%. Plant-ash soda-lime-silica glass (v-Na-Ca) is the earliest known glass type. It was produced in Egypt (e.g., Rehren \& Pusch, 2005; Smirniou \& Rehren, 2011; Tite \& Shortland, 2003) 
Fig. 2 (continued)

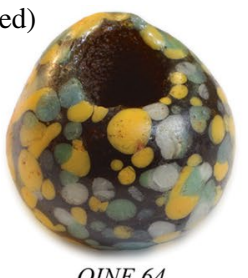

OINE 64

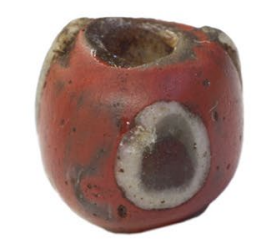

OINE 69

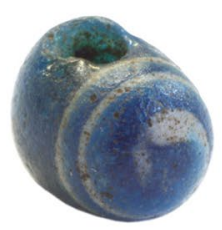

OINE 65

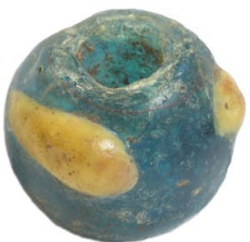

OINE 66

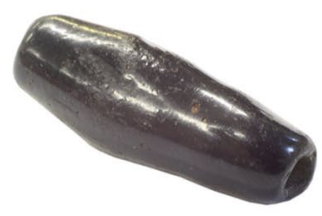

OINE 68

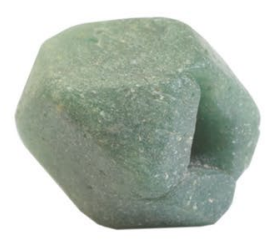

OINE 70

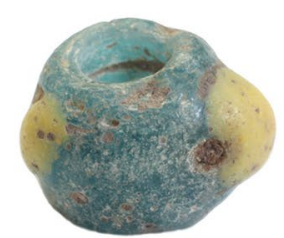

OINE 71

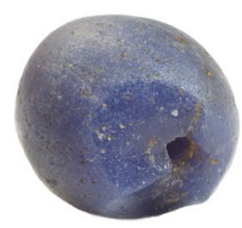

OINE 72

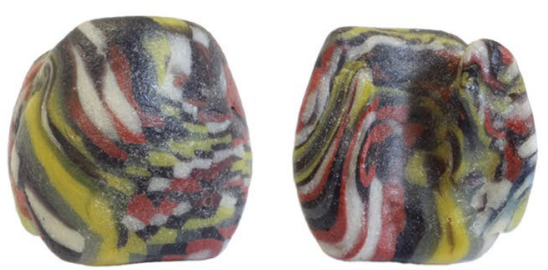

OINE 73

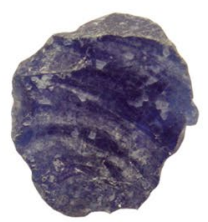

OINE 77

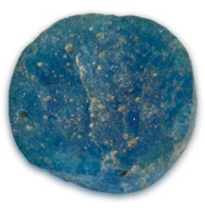

OINE 78

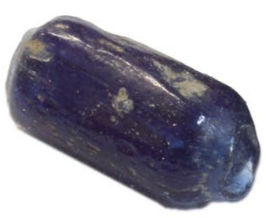

OINE 74

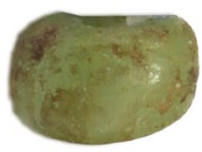

OINE 79

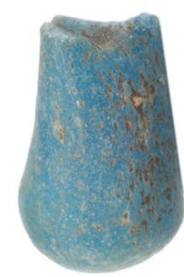

OINE 75

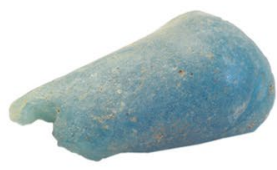

OINE 80

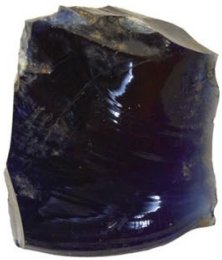

OINE 76

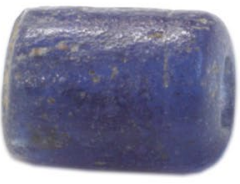

OINE 81 and Mesopotamia (e.g., Shortland et al., 2018) as early as the middle of the second millennium BC. Later, v-Na-Ca glass was made by the Sasanians. This was followed by Islamic glass-makers in a region east of the Euphrates from the third century $\mathrm{BC}$ to about the seventeenth century $\mathrm{AD}$, and by Islamic glass-makers in the East Mediterranean region, Egypt, and the Levant, starting from the mid-ninth century AD (Brill, 2005; Henderson et al., 2016; Mirti et al., 2008, 2009; Phelps, 2016). Based on different levels of $\mathrm{MgO}$ and trace constituents such as $\mathrm{Ti}, \mathrm{Zr}, \mathrm{Cr}$, and $\mathrm{La}$, two subtypes of plant ash-soda glass are distinguished in the OINE assemblage: New Kingdom (v-Na-Ca NK) and Medieval (v-Na-Ca OINE73) (Fig. 4A).
v-Na-Ca NK

A pendant of light blue wound glass decorated with a white spiral trail (OINE65B1, W), found in Nobadian grave R 119 at Qustul and thought to be Meroitic in date (Williams, 1991, p. 146), is part of a v-Na-Ca sub-group. It has low levels of $\mathrm{Rb}$ (about $11 \mathrm{ppm}$ ) and Li (about $5 \mathrm{ppm}$ ). These chemical attributes exclude glass affiliation with contemporary v-Na-Ca Sasanian glass, featuring higher levels of both elements (e.g., Mirti et al., 2009; Then-Obłuska \& Dussubieux, 2016). The two-colored glasses used to make this pendant have trace element levels indicating a Late Bronze Age date. Soda plant ash glass was produced since the middle of the second millennium in Egypt 


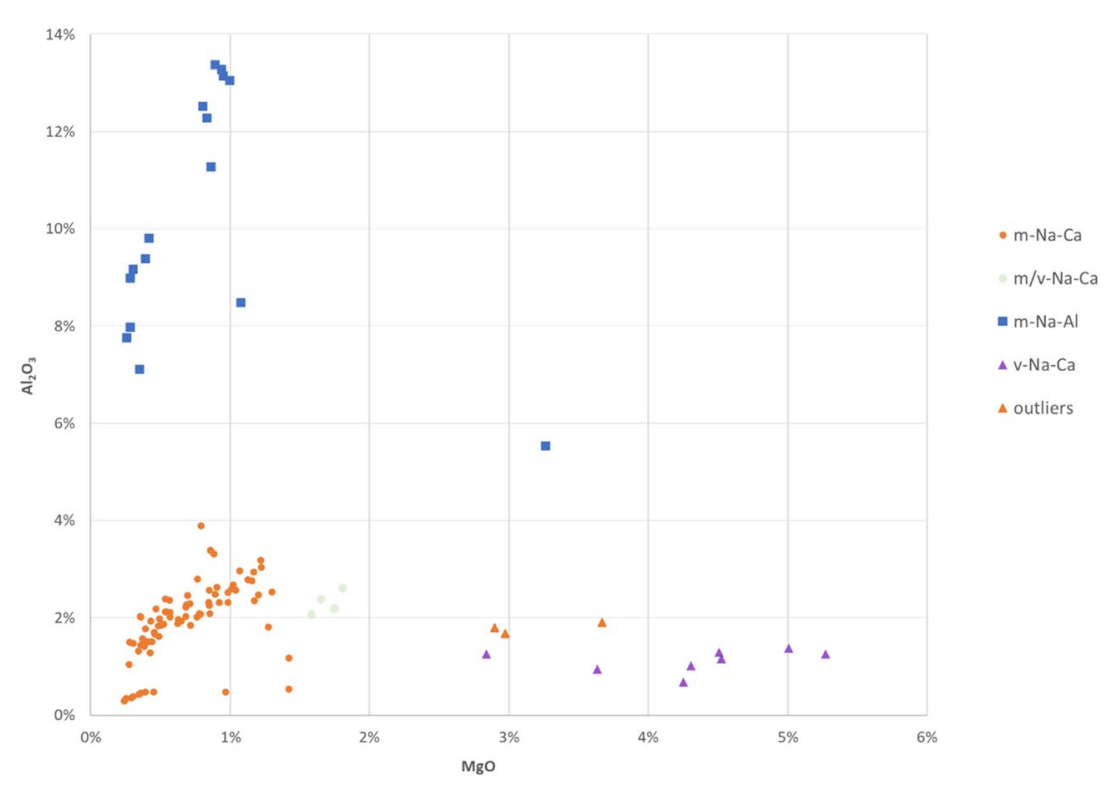

Fig. 3 Chemical variability of the investigated beads: low-alumina soda-lime glass, high-alumina glass, and plant-ash soda-lime glass based on $\mathrm{MgO}$ and $\mathrm{Al}_{2} \mathrm{O}_{3}$ determination (data are given as wt.\%)

Table 1 Glass composition groups for analyzed beads from Lower Nubian sites, arranged by period

\begin{tabular}{lllll}
\hline Glass type & $\begin{array}{l}\text { Number of beads and } \\
\text { glass fragments }\end{array}$ & Lower Nubia & Egypt & Dating \\
\hline v-Na-Ca NK & 2 & New Kingdom 18th Dynasty & & ca. mid-16th-14th c. BCE \\
m-Na-Ca LT/Classic & 5 & 25th Dynasty & mid-8th-mid-7th c. BCE \\
m/v-Na-Ca & 4 & Classic and Late Meroitic & Roman Period & 1st c. BC-mid-4th c. CE \\
m-Na-Ca & 48 & Post-Meroitic (Nobadian) & Late Roman (Early & mid-4th-6th c. CE \\
m-Na-Al 1 & 15 & Christian (Makurian) & Islamic & 7th-14th c. CE \\
v-Na-Ca OINE73 & 1 & & & \\
m-Na-Al 2 & 1 & & &
\end{tabular}

and Mesopotamia, and both production areas can be distinguished by plotting $\mathrm{Zr} / \mathrm{Ti}$ and $\mathrm{Cr} / \mathrm{La}$ ratios. A high ratio of $1000 * \mathrm{Zr} / \mathrm{Ti}>40$ and a low ratio of $\mathrm{Cr} /$ $\mathrm{La}<4$ suggest Egyptian provenance of the glass, while the ratios of $1000^{*} \mathrm{Zr} / \mathrm{Ti}<60$ and $\mathrm{Cr} / \mathrm{La}>4$ indicate Mesopotamian glass (Shortland et al., 2007). Comparison of the two ratios in OINE65 with those in Late Bronze Age glasses from Egypt and Mesopotamia (based on Shortland et al., 2007; Henderson, 2013, Fig. 6.10) reveals similarities with the Egyptian data (Amarna and Malkata) (Fig. 4A).
Undoubtedly, the blue glass (OINE65B) owes its color to the presence of $\mathrm{CuO}(2.5 \%)$, although a contribution of $\mathrm{Fe}_{2} \mathrm{O}_{3}(0.5 \%)$ cannot be excluded. Traces of tin, $\mathrm{SnO}_{2}(0.09 \%)$, Co (61 ppm), and $\mathrm{Ni}$ (62 ppm) might have been brought in accidentally by the copper. All the elements occur in proportions resembling the scores for the "Cu blue" glass from Amarna and Malkata (Shortland \& Eremin, 2006, Table 1). The white glass (OINE $65 \mathrm{~W}$ ) has $\mathrm{CaO}$ at a level of $6.5 \%$ and a very high level of $\mathrm{Sb}_{2} \mathrm{O}_{5}$ (5.1\%) and, like the New Kingdom v-Na-Ca glass from Amarna and Malkata, was decorated with 


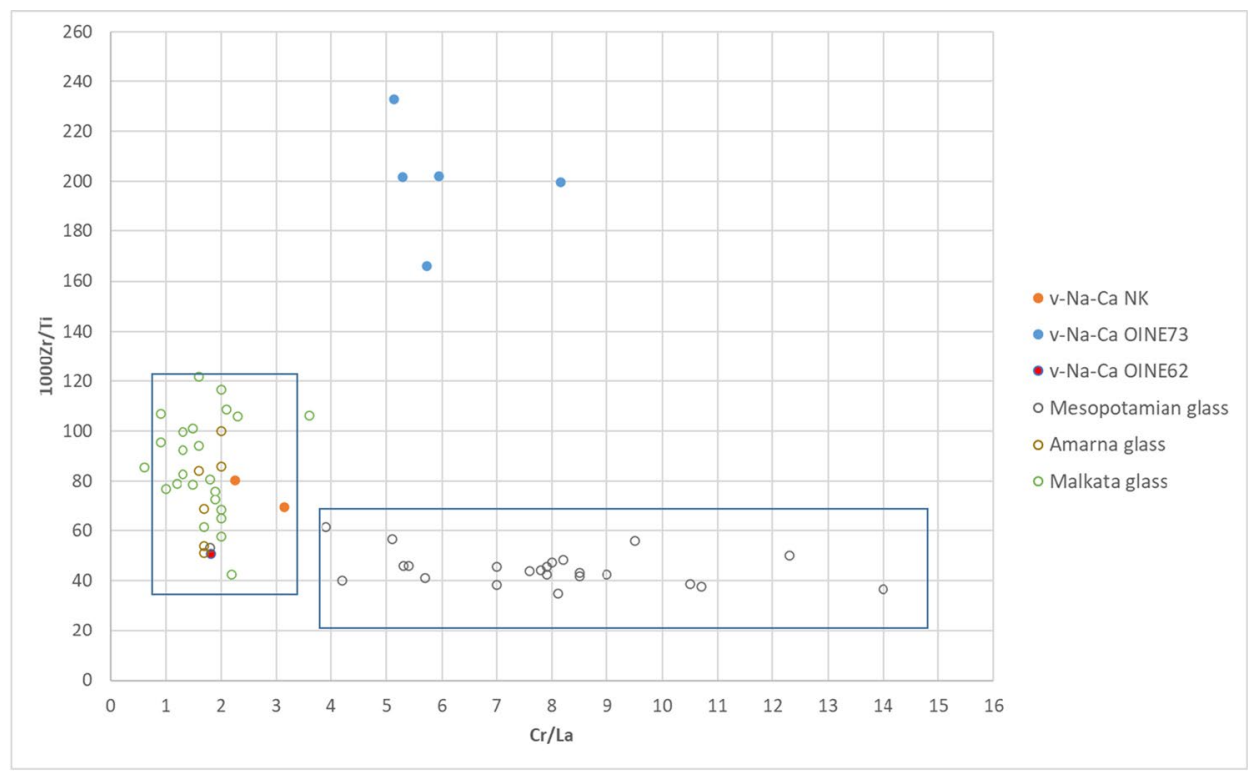

A

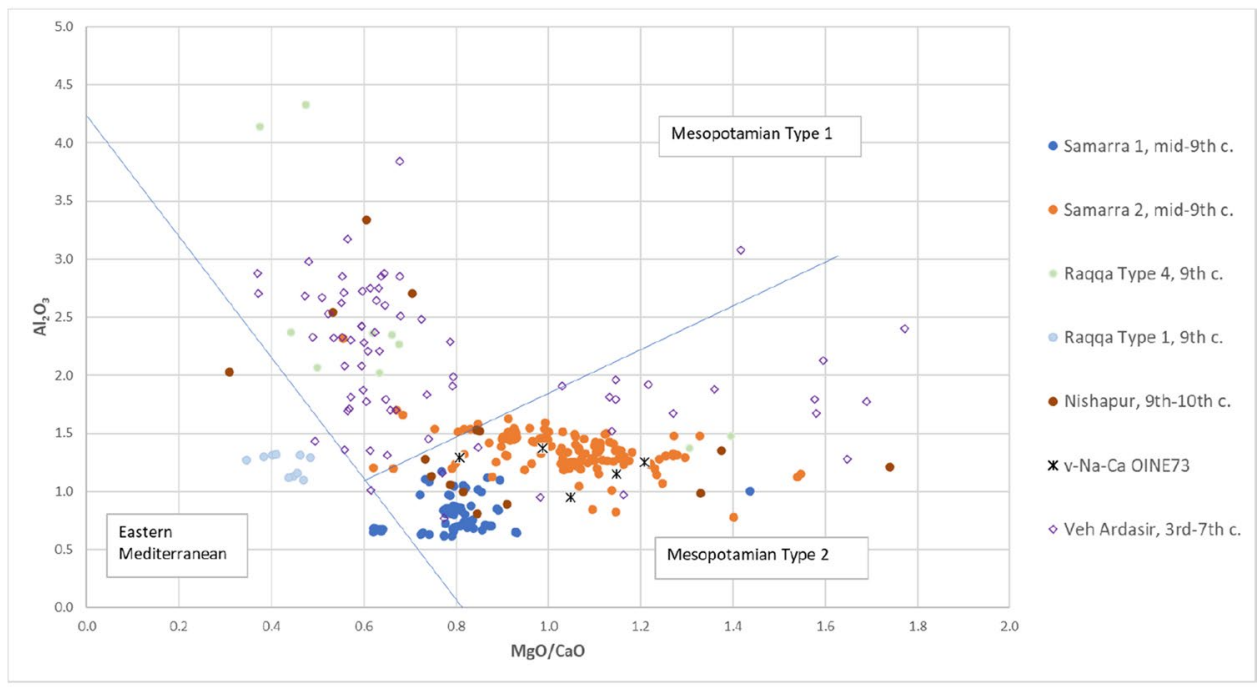

B

Fig. 4 A A biplot of chromium/lanthanum versus 1, 000× zirconium/titanium in OINE v-Na-Ca glass in frames for late Bronze Age glasses from Egypt (Amarna and Malkata) and Mesopotamia (Tell Brak and Nuzi) (based on Shortland et al., 2007); B Biplot of $\mathrm{Al}_{2} \mathrm{O}_{3}$ and $\mathrm{MgO} / \mathrm{CaO}$ showing results for $\mathrm{v}-\mathrm{Na}-\mathrm{Ca}$ glass OINE73, and "Mesopotamian" glass from

calcium antimonate (Shortland \& Eremin, 2006, p. 591, Table 1). Similar proportions of $\mathrm{CaO}$ in the blue and the white glass prompt the conclusion that the latter color was obtained solely by adding antimony to the colorless glass. Antimony precipitated
Samarra 1 \& 2, mid-ninth century AD (Schibille et al., 2018), Raqqa, ninth century AD (Henderson et al., 2016), Nishapur, ninth and tenth century AD (Henderson et al., 2016), and Veh Ardasir, AD 300-700 (Mirti et al., 2008, 2009), within range borders, according to Phelps (2016)

with the calcium in the glass made with soda plant ashes, and calcium antimonate was obtained in this way (Shortland, 2002).

A higher level of $\mathrm{Al}_{2} \mathrm{O}_{3}$ and $\mathrm{Sb}_{2} \mathrm{O}_{5}$ in the white glass (OINE65W) along with traces of cobalt in 
copper blue glass (OINE65B) would exclude its affiliation with later New Kingdom glass from Lisht, dated to the end of the second millennium (Shortland \& Eremin, 2006, p. 596-597, Table 2). Furthermore, the presence of traces of $\mathrm{SnO}_{2}$ in OINE65B would also exclude its affiliation with early New Kingdom blue glass dated to the fifteenth century BC (Shortland \& Eremin, 2006, p. 596-597, Table 2). The OINE65 affiliation with the Amarna and Malkata sites, assumed glass-making centers in the fourteenth century BC (Shortland \& Eremin, 2006), makes this bead stand out from the Nobadian tomb collection. The bead may have been moved from one of the New Kingdom tombs at Qustul (Then-Obłuska, forthcoming; Williams, 1992). Bichrome pendants with a similar trail added spirally are dated to the New Kingdom period (Spaer, 2001, cats. 72-74). Another bead, OINE62, found in a 25th Dynasty grave, features higher $\mathrm{K}_{2} \mathrm{O}(1.3 \%)$ and high $\mathrm{MgO}(2.8 \%)$, and its translucent purple wound glass has $0.8 \% \mathrm{MnO}$ and $0.7 \% \mathrm{Fe}_{2} \mathrm{O}_{3}$. Although the New Kingdom glass usually features more elevated magnesium and potassium (Shortland \& Eremin, 2006), OINE62 still seems to fit this glass group since it typologically resembles other New Kingdom beads (Then-Obłuska in press: cat. 324.1, from Qustul R 94 dated to New Kingdom Post-Amarna period; Metropolitan Museum of Arts, New York, MET 11.215.661, from Malqata, Palace of Amenhotep III, ca. 1390-1353 BC). Also, comparing its $\mathrm{Cr} / \mathrm{La}$ and $1000 * \mathrm{Zr} / \mathrm{Ti}$ ratios with records for Egyptian and Mesopotamian glass makes its attribution to New Kingdom Egyptian glass fairly apparent (Fig. 4A).

\section{v-Na-Ca OINE73}

Other v-Na-Ca compositions belong to a polychrome bead fragment, OINE73A-E, found in a Nobadian house (fourth-sixth centuries AD), thus implying the v-Na-Ca OINE73 glass could have been produced during the Sasanian period. To date, the OINE73A$\mathrm{E}$ data for the various colored glass fragments were placed in a $\mathrm{MgO} / \mathrm{CaO}$ vs. $\mathrm{Al}_{2} \mathrm{O}_{3}$ graph. The result demonstrated a distinction between the soda plant ash glass of Eastern Mediterranean provenance (Syria, Egypt, and Palestine/Levant) and the soda plant ash from the Mesopotamian region (northern Syria, Iran, and Iraq), dated between the eighth and tenth centuries AD (McIntosh et al., 2020; Phelps, 2016;
Schibille et al., 2019). Further, two groups have been distinguished in the Mesopotamian glass: Mesopotamian Type 1 with samples from Veh Ardasir (third through seventh centuries AD) and Raqqa (type 4; ninth century AD), and Mesopotamian Type 2 with samples from Samarra (Schibille et al., 2018, Fig. 6). The results for OINE73, with $\mathrm{Al}_{2} \mathrm{O}_{3}$ (about $<1.5 \%$ ), fit the Mesopotamian Type 2 (Phelps, 2016; Schibille et al., 2018; Fig. 6), particularly the Samarra 2 subgroup (Fig. 4B).

Analyses of (de)colorants and opacifiers in OINE73 are compatible with an Islamic glassperiod affiliation. All glasses (yellow, black, red, and colorless) contain some concentrations of $\mathrm{SnO}_{2}$ and $\mathrm{PbO}(>2 \%)$. The white $\left(\mathrm{PbO}_{2}\right.$ and $\left.\mathrm{SnO}_{2}=1.6 \%\right)$ and yellow $\left(\mathrm{PbO}=8.7 \%, \mathrm{SnO}_{2}=1.05 \%\right)$ colors were opacified with tin oxide and lead stannate, accordingly. The yellow color has some traces of antimonate $(0.04 \%)$. Although, after the fourth century $\mathrm{AD}$, tin, instead of antimonate, was used as an opacifier (Tite et al., 2008), occasional use of antimonate and arsenic was recorded for Merovingian- and Islamic-period yellow and greenish-yellow glass (Neri et al., 2019). With all the above in mind, the OINE73 fragment may be assumed to be a Medieval intrusion in the context of the Serra East Nobadian household rather than a Sasanian production. In fact, OINE73A-E is the fragment of a bead made of mosaic glass with a so-called checkerboard pattern already known in the Hellenistic period, and its production continued through Medieval times (e.g., Spaer, 2001, p. 120). The glass might have arrived through the Red Sea ports of Aidhab (used as a port at least from the time of the Fatimid conquest of Egypt in AD 969) and Suakin, some 230 miles south of 'Aidhab, founded in the ninth century.

\section{m-Na-Ca glass}

Most analyzed OINE samples $(n=84)$, featuring low alumina $(<3 \%)$, also have low magnesia $(<1.5 \%)$ concentrations, indicating the use of mineral soda as flux. Soda-lime glass, using mineral soda as a flux - usually in the form of natron from Wadi el Natrun in Egypt - was manufactured in Egypt and the Syro-Palestinian region for two millennia, between the tenth century BC and mid-ninth century AD (e.g., Phelps et al., 2016; 
Shortland et al., 2006). Dated to the beginning of the tenth century BC, glass vessels from Theban tomb 320 are characterized by low potassium and magnesium $(<1.2 \%)$, soda $(18.2-23.4 \%)$, calcium (1.3-4.8\%), and alumina ( $>2.1 \%)$ and, most likely, were made from sand and mineral soda (SchlickNolte \& Werthmann, 2003). Natron-based glass, usually containing low levels of magnesia and potash $(<1.5 \%)$ (LMLK glass) and moderate levels of $\mathrm{Al}_{2} \mathrm{O}_{3}$ (0.5 to 3\%) (e.g., Panighello et al., 2012), became widespread in the Southern, Eastern, and Western Mediterranean (e.g., Shortland et al., 2006). Some samples of the OINE m-Na-Ca type have very low levels of $\mathrm{Al}_{2} \mathrm{O}_{3}(<0.5 \%)$ and low levels of some trace elements (m-Na-Ca LT), suggesting the use of silica sources different from that of the m-Na-Ca glass produced between the Hellenistic and Islamic periods. In the sample discussed, this type of glass is found mainly in the first through sixth century-AD bead types. Hence, they are labeled Roman glass (m-Na-Ca R).

\section{m-Na-Ca Roman}

Seventy-two samples have low levels of magnesia $(<1.5 \%)$, potash $(<1 \%)$, and low to moderate levels of alumina (1-3.5\%), indicating the use of mineral soda as flux and sand as silica. All beads made of $\mathrm{m}-\mathrm{Na}-\mathrm{Ca}$ glass come from Nobadian graves, although many were reused Meroitic/Early Roman bead types (e.g., OINE05, 16, 22, 32, 33, 34, 36, 55, 71 , and 72). The southeastern part of the Mediterranean basin and the Levantine coast owe their sand deposits to the Nile drainage into the Mediterranean Sea. The sediments flow, primarily the wave-induced longshore currents that cause changes in the proportion of selected minerals, may help determine certain glass types' provenance. For example, declining ratios of zircons (Barfod et al., 2020) may serve as a criterion to separate Egyptian and Levantine glasses. Since Egyptian sand would contain higher zirconium concentrations, Egyptian glass should have lower yttrium to zirconium (Y/Zr) and cerium to zirconium $(\mathrm{Ce} / \mathrm{Zr}$ ) ratios when compared to glass from the Levant, produced from sand with lower $\mathrm{Zr}$ concentrations (Van Strydonck et al., 2018). Calculating the yttrium to zirconium (Y/Zr) and cerium to zirconium $(\mathrm{Ce} / \mathrm{Zr})$ ratios for the low-alumina soda-lime glass from Nubia would be indicative of an Egyptian provenance for OINE06, 15R, 16, 28Y, 32B1, 33, 34, $36,37,41,44,55,56,71 \mathrm{Y}, 72,75,77,78$, and 80. A number of samples are of Levantine provenance (OINE06, 15R, 16, 28Y, 32Bl, 33, 34, 36, 37, 41, 44, 55, 56, 71Y, 72, 75, 77, 78, and 80) (Fig. 5A). The Ti levels for the OINE samples usually score low in the group of Levantine glass ( $<400 \mathrm{ppm})$, confirming their attribution based on the $\mathrm{Y} / \mathrm{Zr}$ and $\mathrm{Ce} / \mathrm{Zr}$ ratios. However, some exceptions exist (OINE80, Levantine and $\mathrm{Ti}>500 \mathrm{ppm}$; OINE44, 55, Levantine glass and $\mathrm{Ti}>470 \mathrm{ppm}$ ) but to a limited extent. The Levantine glass in the OINE assemblage was partly identified for the Meroitic/Early Roman bead types (OINE16, $32,33,34,36,71,72)$. Nearly all Nobadian translucent and semi-translucent blue glass beads feature comparable compositions with $\mathrm{CuO}, 0.3-1.8 \%$, and antimony hardly present (OINE06, 37, 44, 66B, 71B, $75,78,80)$. The diagnostic Nobadian bead types, especially the wound bodies of eye beads and teardrop pendants (see below), appear to be made mostly of Levantine glass (Fig. 5B). Other beads (OINE05, $22,55 \mathrm{~B})$ have elevated levels of $\mathrm{CuO}(1.6-2.4 \%)$ and significant quantities of $\mathrm{Sb}_{2} \mathrm{O}_{5}(0.6-1.2 \%)$.

An elevated cobalt (555-1629 ppm) content was the main colorant of the dark blue beads (OINE02BCo, 09, 13, 15BCo, 16BCo, 25, 30, 31BCo, 33BCo, 34BCo, 35, 41, 55BCo, 72, 74, 81) and workshop chunks (OINE76-77). The cobalt used for the natron-type beads is not unambiguously associated with any particular impurities, a trademark of Roman cobalt sources (Gratuze et al., 1992). According to Gratuze et al. (2018), natron glass colored with cobalt features a relatively constant pattern with a high $\mathrm{CoO} / \mathrm{NiO}$ ratio $(\mathrm{CoO} / \mathrm{NiO}>24)$. Sometime between the late fourth and the beginning of the sixth century, the $\mathrm{CoO} / \mathrm{NiO}$ ratios experience a drastic decrease $(2.2<\mathrm{CoO} / \mathrm{NiO}<5.1)$ (Gratuze et al., 2018, p. 18). In the OINE assemblage, only a few dark blue glass beads have a high $\mathrm{Co} / \mathrm{Ni}$ ratio $(>24$ for OINE16, 33, 72), while the glass of these Nobadian-dated beads may have been produced earlier, in the Meroitic period. Only one bead in the studied assemblage has a low $\mathrm{Co} / \mathrm{Ni}$ ratio of 5.9 (OINE32). In contrast, most samples have ratios below 24 but higher than 5 (OINE02, 09, 13, 15, 25, 30, 31, 34, 35, $41,55,74,76,77,81$ ), which may have resulted from recycling earlier glass mixed with the glass of a later date (Fig. 5C). Many of these samples were made of Egyptian glass (Fig. 5B). It seems probable that the 
Fig. 5 A Ratios of $\mathrm{Y} / \mathrm{Zr}$ to $\mathrm{Ce} / \mathrm{Zr}$ showing Egyptian and Levantine origins for the low-alumina soda-lime subtypes; B Ratios of Y/Zr to $\mathrm{Ce} / \mathrm{Zr}$ showing Egyptian and Levantine origins for $\mathrm{Co}$ and $\mathrm{Cu}$ blue glasses; $\mathbf{C}$ A biplot of $\mathrm{Co} / \mathrm{Ni}$ versus $\mathrm{Zn}$ (ppm) in OINE m-Na-Ca Roman glass

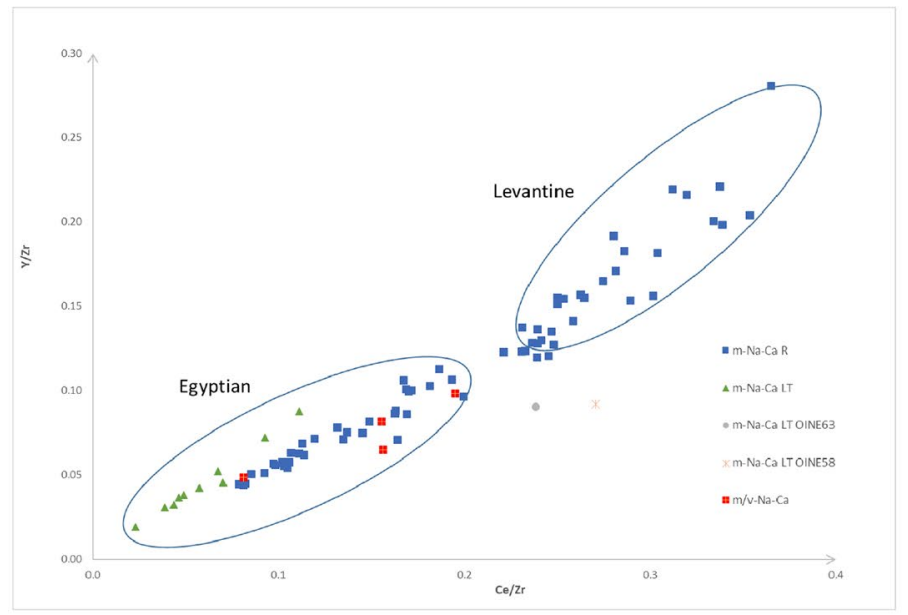

A

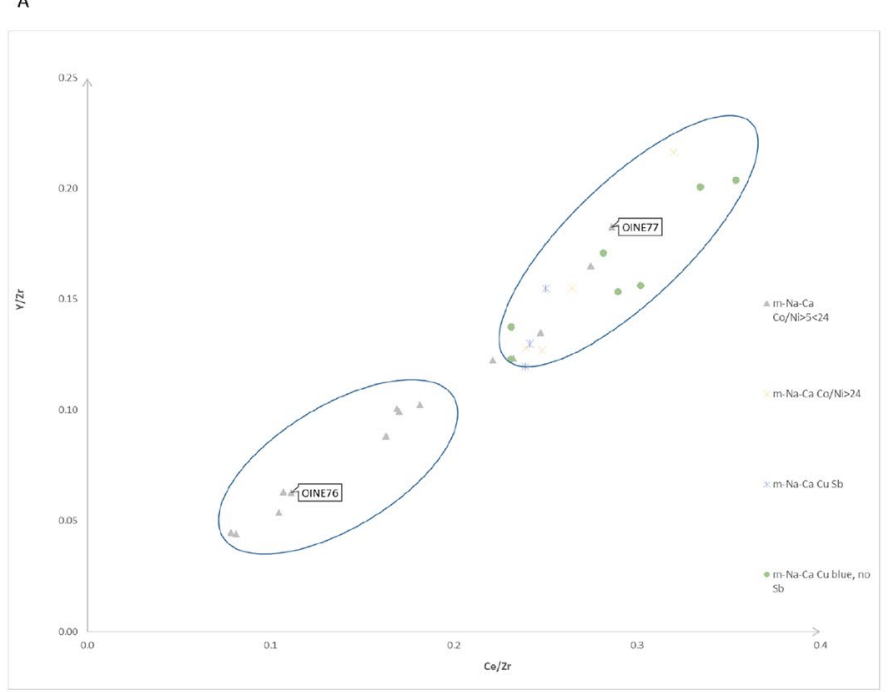

B

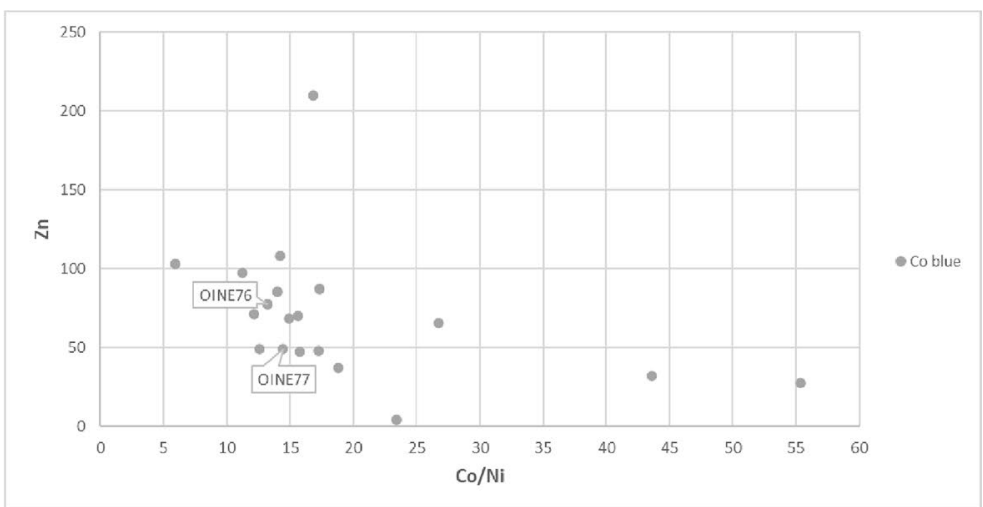

C period between the late fourth and the sixth century was the time when earlier, Early Roman cobalt glass of $\mathrm{Co} / \mathrm{Ni}$ ratio above 24 (Gratuze et al., 2018) would have been mixed with new resources characterized by the $\mathrm{Co} / \mathrm{Ni}$ ratio between 2.2 and 5.1 (Gratuze et al., 2018). 
The m-Na-Ca beads were made with diverse techniques, well recognized in Roman and late antique northeast Africa (e.g., Then-Obłuska \& Wagner, $2019 \mathrm{~b}$ ) and beyond. These are beads made of drawn and segmented glass and gold-in-glass as produced in Alexandria, Egypt (Kucharczyk, 2011; Rodziewicz, 1984). Other beads were made of the wound, folded, and rod-pierced glass, and many of them might have been manufactured locally.

\section{m-Na-Ca LT/Classic}

Nine m-Na-Ca samples (OINE59, 60B1-Y, 61, 64Bl$\mathrm{B}-\mathrm{Gr}-\mathrm{W}-\mathrm{Y})$ are characterized by very low levels of $\mathrm{MgO}, \mathrm{K}_{2} \mathrm{O}, \mathrm{Al}_{2} \mathrm{O}_{3}\left(\leq 0.5 \%\right.$ ), and $\mathrm{Fe}_{2} \mathrm{O}_{3}$ (average of $0.8 \%)$. They also have low levels of silica-related impurities and other earth trace elements (e.g., Ti, Sr, $\mathrm{La}, \mathrm{Rb}$, and $\mathrm{Ba}$ ) compared with the m-Na-Ca Roman glass type. Although OINE58 and 63 feature $\mathrm{MgO}$, $\mathrm{K}_{2} \mathrm{O}$, or $\mathrm{Al}_{2} \mathrm{O}_{3}$ levels higher than other examples in the m-Na-Na LT glass group, their trace elements $(\mathrm{Sr})$ still fit the "low trace" natron group. For this reason, they have been assigned to the m-Na-Ca LT glass group.

The OINE m-Na-Ca LT composition suggests a very clean silica source, i.e., a better quality of sand or even quartz pebbles, for glass production (Shortland \& Eremin, 2006). Based on the $\mathrm{Zr}$ level, two types of "classic natron" glass were distinguished: low-Zr and high-Zr natron glass (Conte et al., 2019). Low levels of $\mathrm{Zr}(<9 \mathrm{ppm})$ and the lowest possible levels of alumina, magnesia, potash, iron, and REEs in a glass sample indicate, according to the authors, the use of quartz pebbles (Conte et al., 2019, table 4). However, the Zr level $(>21<272 \mathrm{ppm})$ in the OINE $\mathrm{m}-\mathrm{Na}-\mathrm{Ca} \mathrm{LT}$ glass would point to a high-Zr affiliation, and this, in turn, would exclude the use of quartz pebbles. High lime concentrations in the m-Na-Ca glass came with sand collected from a beach and thus contained seashell fragments. A relatively low $\mathrm{Sr}$ content linked to a rather high $\mathrm{CaO} / \mathrm{SrO}$ ratio (362) is thought to result from the addition of diagenetically altered shells, partly recrystallized once their initial strontium contents had been lost (Conte et al., 2019; Wedepohl et al., 2011).

As for the m-Na-Ca R glass, the authors compared yttrium to zirconium ( $\mathrm{Y} / \mathrm{Zr}$ ) and cerium to zirconium $(\mathrm{Ce} / \mathrm{Zr})$ ratios of the $\mathrm{m}-\mathrm{Na}-\mathrm{Ca} \mathrm{LT}$ glass samples with the ratios for glass produced in the
Levantine and Egyptian regions, respectively. As shown in Fig. 5A, the m-Na-Ca LT glass samples follow a trend observed for glass samples of Egyptian provenance. Low $\mathrm{Al}_{2} \mathrm{O}_{3}(<0.5 \%)$ levels undermine any comparison of the $\mathrm{m}-\mathrm{Na}-\mathrm{Ca}$ LT glass with most of the low $\mathrm{MgO}$ and $\mathrm{K}_{2} \mathrm{O}(<0.5 \%)$ natron glasses from the eighth through the fourth century BC Europe (e.g., Macedonia; Blomme, et al., 2017). Still, similar compositions have been reported from various French sites, dated to the beginning of the Iron Age, in the ninth through second centuries BC (Gratuze, 2009, Fig. 2). One of these groups features low potassium and low alumina, each at a level of about $0.5 \%$. Some samples in this group come from the Champlay context dated to ca. 750-500 BC or 750-400 BC (Gratuze, 2009, Fig. 2). An antimony decolored glass sample from Sardis (Turkey), dated to ca. 700-500 BC (Ignatiadou, 2000), and a turquoise decoration of the Bologna eye bead from 500-300 BC-Etruscan context in northern Italy feature similar very low $\mathrm{Al}_{2} \mathrm{O}_{3}$ results (Arletti et al., 2010, IG45). Interestingly, an opaque red chunk with $\mathrm{MgO}, \mathrm{K}_{2} \mathrm{O}$, and $\mathrm{Al}_{2} \mathrm{O}_{3}<0.5 \%$, was found in Persepolis, dated to around the fifth century BC (Brill, 1999, IIH:198). Additionally, a glass of probable Egyptian provenance, featuring $\mathrm{Mg}$, $\mathrm{K}$, and $\mathrm{Al},<0.5 \%$, low levels of some trace elements that resemble the m-Na-Ca LT glass, and a so-called "classic natron," was identified in the Iron Age Italy, ca. 800-500 BC (Conte et al., 2019).

The study by Conte et al. (2019), using the measurements of selected elements' levels, also presents ways to date the natron black glass more adequately. Some black samples with low lime, high iron, and high trace and REEs contents are dated to ca. 900-700 BC. Other samples (TG3bl, TG12bl, and TG13bl), characterized by lower alumina, titania, iron, and higher lime concentrations, are comparable with the OINE m-Na-Ca LT, and dated to ca. 700-500 BC.

An analysis of opacifiers in the m-Na-Ca LT group confirms its early date. Yellow glass in OINE60Y and $64 \mathrm{Y}$ features significant $\mathrm{Sb}_{2} \mathrm{O}_{5}(1.2 \%, 1.1 \%)$ and $\mathrm{PbO}$ $(15 \%, 9.7 \%)$ levels and a complete lack of tin. Antimony-based opacifiers (i.e., lead antimonate yellow) were used, in the Near East and Egypt, from the onset of glass production, ca. $1500 \mathrm{BC}$, through the Roman period (Turner \& Rooksby, 1959). Towards the end of the Roman period (especially fourth century AD 


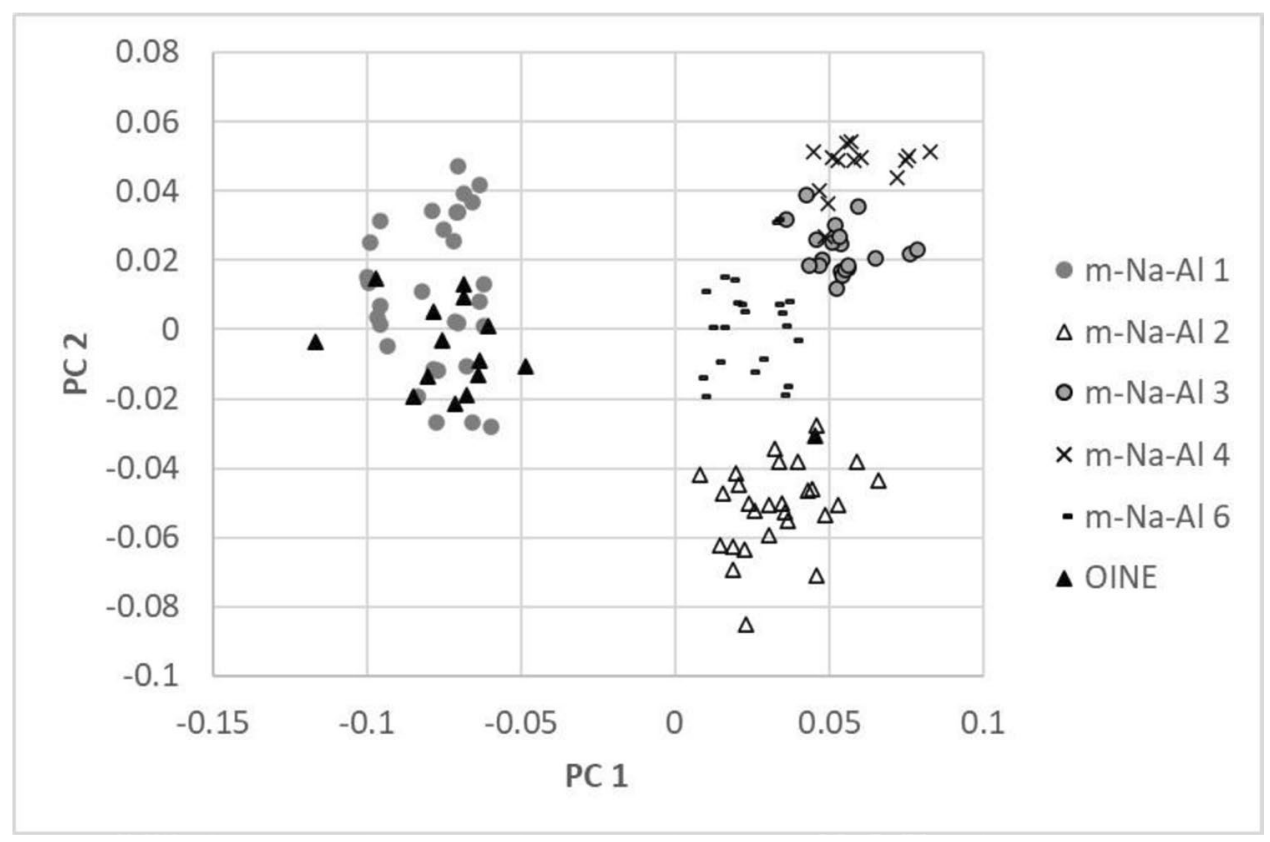

Fig. 6 Principal components 1 and 2 calculated using the concentrations of $\mathrm{MgO}, \mathrm{CaO}, \mathrm{Sr}, \mathrm{Zr}, \mathrm{Cs}, \mathrm{Ba}$, and $\mathrm{U}$ for samples belonging to glass groups m-Na-Al 1, 2, 3, 4, and 6 and for samples from Nubia. The m-Na-Al 1 glass samples are unpublished data from Sri Lanka and South India, the m-Na-Al 2 glass samples are beads from Chaul (Dussubieux et al., 2008), the m-Na-Al 3 glass samples are beads from Kopia (Dussubieux \& Kanungo, 2013), the m-Na-Al 4 are glass vessel fragments from Sumatra (Dussubieux, 2009), and the m-Na-Al 6 glass are from the site of Juani Primary School (Dussubieux \& Wood, 2021)

in Wadi Howar, dated ca. 1100-400 BC, provided no trace elements feasibly comparable with OINE glass (Daszkiewicz \& Lahitte, 2013). Some compositional similarities in OINE58 can be recognized in an orange bead of Egyptian glass, featuring low levels of $\mathrm{MgO}, \mathrm{K}_{2} \mathrm{O}$, and $\mathrm{Al}_{2} \mathrm{O}_{3}(<0.5 \%$ ) (Then-Obłuska \& Wagner, 2019b, SNM07). Its elemental levels (e.g., $\mathrm{Al}_{2} \mathrm{O}_{3}$ 0.25\%, Sr 93 ppm, $\mathrm{Zr} 13.8$ ppm, and $\mathrm{Ti}$ $319 \mathrm{ppm})$ resemble those in m-Na-Ca LT glass; however, the $\mathrm{NaO}(2.98 \%)$ and $\mathrm{CaO}(1.8 \%)$ levels are much lower. The bead was found in a Sedeinga grave, accompanied by several other beads of the same type and Napatan amulets (Then-Obłuska, 2015b). A Napatan date for this glass type can be supported by evidence from Nag Shayeg, where beads of this type have been found in a probable Napatan tomb, T131 (Then-Obłuska \& Wagner, 2019b, Pl. 28.1-28.2). 
$\mathrm{m} / \mathrm{v}-\mathrm{Na}-\mathrm{Ca}$ glass

Four glass samples (OINE03, 45, 46, 53) with low alumina levels, moderate $\mathrm{K}_{2} \mathrm{O}(<1.5 \%)$ level, and elevated concentrations of $\mathrm{MgO}(>1.5 \%)$ suggest the use of mineral-soda and plant ash or the specific soda plant ashes. The $\mathrm{K}_{2} \mathrm{O}$ or $\mathrm{MgO}>1.5 \%$ values are commonly believed to indicate the use of organic material in the form of plant or wood ash in the glass batch. Glass with higher concentrations of $\mathrm{MgO}$ or/and $\mathrm{K}_{2} \mathrm{O}$ was identified and discussed for early Roman glasses in Egypt (Nenna \& Gratuze, 2009; Then-Obłuska \& Dussubieux, 2016), and the Egyptian $\mathrm{m} / \mathrm{v}-\mathrm{Na}-\mathrm{Ca}$ glass was found mainly in the first through mid-fourth centuries AD Nubia (Then-Obłuska \& Dussubieux, 2021; Then-Obłuska \& Wagner, 2019a). The present study confirms their Egyptian provenance (Fig. 5A), and the OINE $\mathrm{m} / \mathrm{v}-\mathrm{Na}-\mathrm{Ca}$ glass beads in this assemblage were most probably Meroitic items reused in Nobadian graves.

m-Na-Al glass

Sixteen samples have high alumina $(>7 \%)$ and low magnesia $(<2 \%)$ concentrations, indicating the use of mineral-soda flux (m-Na-Al). The mineral-soda high alumina glass beads, with relatively high $(>5 \%)$ concentrations of alumina and trace elements, are particularly common in India where, undoubtedly, they were manufactured (Brill, 2003; Dussubieux et al., 2010, 2021). Low magnesia $(<2 \%)$ concentrations indicate the use of mineral-soda flux. Based on different trace element levels, two sub-types have been identified within the OINE assemblage: 15 samples were made of $\mathrm{m}-\mathrm{Na}-\mathrm{Al} 1$ and one sample of $\mathrm{m}-\mathrm{Na}-\mathrm{Al}$ 2 (Fig. 6).

\section{m-Na-Al 1}

Fourteen samples in the OINE collection have high $\mathrm{Al}_{2} \mathrm{O}_{3}$ contents ranging from 7.1 to $13.4 \%$ (OINE01, 04, 07, 08, 12, 14, 18, 20,23, 39, 49, 50, $52,79)$. The $\mathrm{MgO}$ concentrations in this glass are usually low $(<1 \%)$, while other trace elements, such as uranium with 4-24 ppm, have the highest concentration in this study. Dussubieux and co-authors distinguished a few subtypes of high-alumina mineral soda glass (m-Na-Al 1-4 and 6) based on the contents of five elements: $\mathrm{Sr}, \mathrm{Zr}, \mathrm{Ba}, \mathrm{U}$, and $\mathrm{Cs}$ (Dussubieux et al., 2010, tab. 3; Dussubieux \& Wood, 2021). Using principal component analysis (PCA) and glass constituents, $\mathrm{MgO}, \mathrm{CaO}, \mathrm{Zr}, \mathrm{Sr}$, $\mathrm{Ba}, \mathrm{Cs}$, and $\mathrm{U}$, the $\mathrm{m}-\mathrm{Na}-\mathrm{Al}$ glass beads found in Nubia were compared with already defined $\mathrm{m}-\mathrm{Na}$ $\mathrm{Al}$ subtypes (m-Na-Al 1-4 and 6), and they showed similarities with the m-Na-Al 1 glass (Fig. 6). The compositions of the 14 high alumina samples of this m-Na-Al 1 glass group (formerly known as "low uranium-high barium glass," Dussubieux et al., 2010) have average contents of $\mathrm{Ba}$ and $\mathrm{U}$ that match the m-Na-Al 1 type (Table 2).

Additionally, one sample, a green drawn and rounded bead OINE11, has a high concentration of $\mathrm{MgO}(3.3 \%), \mathrm{K}_{2} \mathrm{O}(2.2 \%)$, and $\mathrm{Al}_{2} \mathrm{O}_{3}$ (5.6\%), and low $\mathrm{CaO}(3.1 \%)$. The trace element levels match the m-Na-Al 1 group (Table 2). Also, the $\mathrm{PbO}$ (4\%), $\mathrm{CuO}$ $(0.8 \%)$, and $\mathrm{SnO}_{2}(0.5 \%)$ levels fit within the range for the green glass in the m-Na-Al 1 group. OINE11 was
Table 2 Average concentrations and standard deviations of important elements crucial for separating m-Na-Al subtypes (data from Dussubieux et al., 2010), followed by data for the

\begin{tabular}{|c|c|c|c|c|c|c|c|}
\hline & & Ba (ppm) & $\mathbf{U}(\mathbf{p p m})$ & Sr (ppm) & $\mathrm{Zr}(\mathbf{p p m})$ & Cs (ppm) & $\mathbf{R b}$ (ppm) \\
\hline m-Na-Al 1 OINE11 & Nobadian (OINE) & 530 & 2.8 & 447 & 633 & 0.2 & 18 \\
\hline m-Na-Al 1 & Dussubieux et al. (2010) & $931 \pm 432$ & $11 \pm 10$ & $373 \pm 145$ & $561 \pm 420$ & $0.6 \pm 0.4$ & $58 \pm 25$ \\
\hline m-Na-Al 1 & Nobadian (OINE) & $660 \pm 217$ & $8.2 \pm 5.0$ & $381 \pm 93$ & $419 \pm 181$ & $0.4 \pm 0.1$ & $43 \pm 11$ \\
\hline m-Na-Al 2 & Dussubieux et al. (2010) & $357 \pm 114$ & $105 \pm 66$ & $213 \pm 70$ & $168 \pm 91$ & $0.8 \pm 1.0$ & $62 \pm 22$ \\
\hline m-Na-Al 2 & Nobadian (OINE) & 315 & 116 & 204 & 160 & 0.8 & 48 \\
\hline m-Na-Al 3 & Dussubieux et al. (2010) & $353 \pm 43$ & $98 \pm 87$ & $132 \pm 31$ & $193 \pm 27$ & $3.6 \pm 0.7$ & $88 \pm 14$ \\
\hline m-Na-Al 4 & Dussubieux et al. (2010) & $529 \pm 386$ & $91 \pm 66$ & $88 \pm 23$ & $251 \pm 55$ & $3.4 \pm 1.1$ & $75 \pm 18$ \\
\hline
\end{tabular}

high-alumina glasses (m-Na-Al 1, m-Na-Al 2) from the Lower Nubian OINE collection 
found in a Nobadian grave together with glass beads made of m-Na-Al 1 glass, which would confirm its affiliation with high alumina glass of South Indian/ Sri Lankan provenance. The presence of lead and tin in OINE14 ( $\left.\mathrm{PbO}=4.6 \% ; \mathrm{SnO}_{2}=0.54 \%\right)$ suggests the yellow bead was probably colored and opacified by lead stannate. Six semi-translucent pale green samples, OINE08, 18, 23, 39, 50, 79, contain significant quantities of $\mathrm{CuO}(0.3-0.8 \%), \mathrm{PbO}(2-5 \%)$, and $\mathrm{SnO}_{2}$ (0.3-0.6\%), suggesting lead stannate may have contributed to the opacification of the glass. Seven beads, OINE01, 04, 07, 12, 20, 49, 52, are orange and contain high concentrations of copper $(\mathrm{CuO} 7.2-9.2 \%)$, but also a higher concentration of iron (2.3-3.1\%) when compared to the blue, red, and black m-Na-Al 1 glass from both South Asia (Lankton \& Dussubieux, 2006, p. 129, Table 2) and Nubian sites (ThenObłuska \& Wagner, 2019b). The orange samples are also characterized by high levels of $\mathrm{MgO}, \mathrm{K}_{2} \mathrm{O}$, and $\mathrm{P}_{2} \mathrm{O}_{5}$. Phosphorus and lime-rich inclusions were found in an orange m-Na-Al 1 glass sampIe from South Asia. These suggest a possible addition of an apatite-rich ingredient for internal reduction to convert the $\mathrm{Cu}^{2+}$ into $\mathrm{Cu}_{2} \mathrm{O}$ (Dussubieux et al., 2010) that usually colors glass orange.

The m-Na-Al 1 glass was most probably manufactured in Sri Lanka or South India. Beads made of this glass are found in Sri Lanka and South India, between the second/first century BC and fifth century AD; and in Southeast Asia between the fifth century BC and tenth century AD (Carter, 2016; Dussubieux et al., 2010, tab. 4; Dussubieux \& Gratuze, 2013). Aside from the Southeast Asian finds, the presence of South Indian/Sri Lankan glass beads has also been confirmed at the Early Roman Red Sea port of Quseir, Egypt (Then-Obłuska \& Dussubieux, 2016), in Merovingian-period Europe (Pion \& Gratuze, 2016; Poulain et al., 2013), and Zanzibar, AD 700-1100 (Sarathi et al., forthcoming; Wood et al., 2017).

The South Indian/Sri Lankan glass (m-Na-Al 1, - green, orange, black, yellow, and orange-on-red) has been found in the Nubian Nile Valley between the First Cataract and the confluence of the Niles (Then-Obłuska \& Wagner, 2019a, b), including the mid-fourth century AD samples from the cemeteries of nomadic peoples (Blemmyes) around Kalabsha, representing the northernmost presence of these glass beads in the Nile valley (Then-Obłuska \& Dussubieux, 2021). Beads made of m-Na-Al 1 glass were produced using a technique diagnostic of Indian origin-drawing a glass tube and heat-rounding its sections (Francis, 2002). South Indian or Sri Lankan glass beads have also been macroscopically identified at other sites associated with the Blemmyes: the Early and Late Roman Red Sea port sites of Berenike and Marsa Nakari (Francis, 2002, 2007; Then-Obłuska, 2016, 2017b, 2018a, 2019, 2021) and the Eastern Desert sites of Shenshef and Sikait (Then-Obłuska, 2017a, 2021), thus pointing to the east-west direction of South Asian bead distribution in northeast Africa.

m-Na-Al 2

One sample, OINE57, has low levels of $\mathrm{MgO}(1.1 \%)$ and $\mathrm{K}_{2} \mathrm{O}(1.8 \%)$ and a high level of $\mathrm{Al}_{2} \mathrm{O}_{3}(8.5 \%)$, pointing to its mineral soda high alumina affiliation. When compared with m-Na-Al 1 glass (Table 2, Fig. 6), it displays higher concentrations of $U$ and $\mathrm{Cs}$ and lower concentrations of $\mathrm{Ba}, \mathrm{Sr}$, and $\mathrm{Zr}$ and fits the m-Na-Al 2 group as defined by Dussubieux et al. (2010). The $\mathrm{CuO}$ (0.7\%), $\mathrm{PbO}(2.4 \%)$, and $\mathrm{SnO}_{2}$ $(0.4 \%)$ levels in the green glass suggest the use of lead stannate. The m-Na-Al 2 glass was previously identified at sites dating from the ninth to the nineteenth century $\mathrm{AD}$, located on the west coast of India and the east coast of Africa (Dussubieux et al., 2010). A recent analysis of more beads from the East African coast has helped revise the chronology for this glass and suggested its presence from around the fourteenth century AD onwards. The Indo-Pacific Khami beads from Southern Africa and m-Na-Al 2 beads on the East African coast have been identified as sharing the same composition. Therefore, both can be assigned to around the fourteenth century AD (Dussubieux \& Wood, 2021). Although the m-Na-Al 2 glass beads might have been manufactured in Maharashtra, a recent study using $\mathrm{Sr}, \mathrm{Nd}$, and $\mathrm{Pb}$ isotope analysis suggests that the raw glass was likely procured from a different region, possibly western Uttar Pradesh (Dussubieux et al., 2021). The beads would have been traded across the Indian Ocean through Chaul, south of Mumbai (Wood, 2019). OINE57, found in grave VF68, originally was strung together with other drawn green and black beads and a Mediterranean Sea coral (Corallium rubrum sp.). Since the latest evidence for m-Na-Al 2 glass suggests a new fourteenth century AD dating for the Qustul VF68 grave, it appears fairly probable that the beads and grave 
may belong to the Islamic period in Lower Nubian history.

\section{Glass Bead-making in Lower Nubia}

During the New Kingdom and the 25th Dynasty, glass beads in Lower Nubia were made of Egyptian glass (v-Na-Ca and m-Na-Ca LT) and most probably imported. Although glass and metal-in-glass beads of Egyptian and Levantine m-Na-Ca R glass became very common in Nubian tombs (e.g., Then-Obłuska \& Wagner, 2019b), during the Meroitic period, no evidence of local bead-making has yet been found.

Whereas many beads found at the Nobadian sites were imported (Egypt and South India/Sri Lanka), there is also some scarce evidence for possible beadmaking (re)using glass imported from Egypt and the Levant. Samples OINE70-78 and 80-81 were found at a Serra East Nobadian household bearing traces of a fireplace and the remains of an oven or a kiln interpreted as a bead workshop. A question then arises whether cobalt blue chunks, OINE76 and 77, could have been used there for bead and pendant manufacture. As recent experiments prove, glass can be processed in rudimentary household fire pits where, with the help of blowpipes, temperatures high enough to produce glass beads are achievable (Hodgkinson \& Bertram, 2020).

Chunks and dark blue beads found in this Serra East workshop (OINE74, 76, 77, 81) have comparable $\mathrm{Co} / \mathrm{Ni}$ ratios of between 13.2 and 15.6 that also resemble other dark blue specimens in the Nobadian collection (OINE02BCo, 09, 13, 15BCo, 25, 30BCo, 31BCo, 34BCo, 41, 55BCo) having a $\mathrm{Co} / \mathrm{Ni}$ ratio of between 11.25 and 18.8 (Fig. 5C). The chunks are of Egyptian (OINE76) and Levantine (OINE77) origin, also attested for cobalt blue glass beads in Lower Nubia (Fig. 5B). This observation seems to verify the hypothesis that the Serra East chunks were used in the local bead-making process.

Translucent and semi-translucent copper blue beads with yellow spots (OINE66B, 71B) and teardrop pendants (OINE37, 44, 75, 78, 80) were found in the workshop and graves. A lack of antimonate characterizes the blue glass, and the biplot of $\mathrm{Y} / \mathrm{Zr}$ to $\mathrm{Ce} / \mathrm{Zr}$ ratios indicates its Levantine origin (Fig. 5B). While the Levantine glass beads themselves are uncommon finds in Nubia in the period under discussion (Then-Obłuska \& Wagner, 2019b), a glass of that type was undeniably used in the production of diagnostic Nobadian ornaments, most probably locally made from reused Levantine glass. Indeed, teardrops of Levantine glass and those of high-alumina glass of uncertain provenance have already been recorded from Lower Nubia (Then-Obłuska \& Wagner, 2019a, b: SJE02 and SJE25 accordingly). It thus appears these pendants may have been produced locally using glass from different sources.

Only two Makuria period specimens were analyzed: an imported glass (v-Na-Ca OINE73) and an imported item (m-Na-Al 2). We cannot provide chemical compositional results supporting the idea of glass bead-making during the Makuria period, but we must mention a workshop at the Early Christian site of Debeira in Lower Nubia that yielded much ash and large pieces of unworked glass remains and a bead of similar glass (Shinnie \& Shinnie, 1978, p. 44). This, in turn, implies a need for further typological and archaeometric evidence to test the hypothesis of local glass bead production in Lower Nubia.

\section{Conclusions}

The analysis of glass beads from Lower Nubia, a now-submerged region, reveals developments in bead glass chemistry over three millennia in Northeast Africa, encompassing the New Kingdom (v-NaCa NK), 25th Dynasty (m-Na-Ca LT), Early Roman/ Meroitic (m-Na-Ca R, m/v-Na-Ca), Late Roman/ Nobadian (m-Na-Ca R, m-Na-Al 1), Makurian (v-Na$\mathrm{Ca}$ OINE73), and possibly Islamic (m-Na-Al 2) periods. This study of glass provenance presents the first-ever dataset attesting to Egyptian glass from the New Kingdom (v-Na-Ca NK) and 25th Dynasty periods (m-Na-Ca LT/Classic) in Lower Nubia. It also presents new evidence for Egyptian and Levantine m-Na-Ca glass in the Early Roman/Meroitic and Late Roman/Nobadian periods. Moreover, the study offers new data for South Indian/Sri Lankan glass bead imports in Late Antique northeast Africa (m-Na-Al 1). Furthermore, it provides the first evidence for the presence of "Mesopotamian" Islamic glass ( $\mathrm{v}-\mathrm{Na}-\mathrm{Ca}$ OINE73) and Indian glass (m-Na-Al 2) in Medieval northeast Africa.

Lower Nubia mostly imported glass beads between the fourteenth century BC and fourteenth century 
AD. However, the presence of cobalt blue chunks and beads, both having similar $\mathrm{Co} / \mathrm{Ni}$ ratios and found in a Late Antique bead workshop, seems to corroborate the hypothesis of the local bead and pendant manufacture. This assumption seems to be further confirmed by the presence, in the workshop, of a diagnostically Nobadian pendant type, i.e., copper blue teardrops, locally produced using different but mainly Levantine glass sources. Beadmaking in medieval Nubia requires further investigation.

Acknowledgements Joanna Then-Obłuska wishes to thank Dr. Bruce B. Williams for the opportunity to study the OINE bead materials. Both authors thank Dr. Jean M. Evans, Chief Curator and Deputy Director for Collections and Exhibitions; Laura D'Alessandro, Head, Conservation Laboratory, and Helen McDonald, Registrar, in the Oriental Institute Museum University of Chicago for making this study possible. Dr. Jacke Phillips, Dr. Shadia Taha, and Dr. Magdalena M. Woźniak are appreciated for all their comments and suggestions.

Open Access This article is licensed under a Creative Commons Attribution 4.0 International License, which permits use, sharing, adaptation, distribution and reproduction in any medium or format, as long as you give appropriate credit to the original author(s) and the source, provide a link to the Creative Commons licence, and indicate if changes were made. The images or other third party material in this article are included in the article's Creative Commons licence, unless indicated otherwise in a credit line to the material. If material is not included in the article's Creative Commons licence and your intended use is not permitted by statutory regulation or exceeds the permitted use, you will need to obtain permission directly from the copyright holder. To view a copy of this licence, visit http://creativecommons.org/licenses/by/4.0/.

\section{References}

Adams, W. Y. (1977). Nubia: Corridor to Africa. Allen Lane. Arletti, R., Maiorano, C., Ferrari, D., Vezzalini, G., \& Quartieri, S. (2010). The first archaeometric data on polychrome Iron Age glass from sites located in northern Italy. Journal of Archaeological Science, 37(4), 703-712. https://doi.org/10.1016/j.jas.2009.11.001

Barfod, G. H., Freestone, I. C., Lesher, C. E., Lichtenberger, A., \& Raja, R. (2020). 'Alexandrian' glass confirmed by hafnium isotopes. Scientific Reports, 10, 11322.

Blomme, A., Degryse, P., Dotsika, E., Ignatiadou, D., Longinelli, A., \& Silvestri, A. (2017). Provenance of polychrome and colourless 8th-4th century BC glass from Pieria, Greece: A chemical and isotopic approach. Journal of Archaeological Science, 78, 134-146.

Brill, R. H. (1999). Chemical analyses of early glasses, Vol. 2, The Corning Museum of Glass, Corning.

Brill, R. H., (2003). The glassmakers of Firozabad and the glassmakers of Kapadwanj: Two pilot video projects. Annales du 15e Congrès de l'Association Internationale pour l'Histoire du Verre (pp. 267-268). AIHV, Nottingham.

Brill, R. H., (2005). Chemical analyses of some Sasanian glasses from Iraq. In D. Whitehouse (Ed.)Sasanian and Post-Sasanian Glass in the Corning Museum of Glass. Annexe 2 (pp. 65-95). Corning Museum of Glass, New York.

Carter, A. K. (2016). The production and exchange of glass and stone beads in Southeast Asia from 500 BCE to the early second millennium CE: An assessment of the work of Peter Francis in light of recent research. Archaeological Research in Asia, 6, 16-29.

Conte, S., Matarese, I., Vezzalini, G., Pacciarelli, M., Scarano, T., Vanzetti, A., Gratuze, B., \& Arletti, R. (2019). How much is known about glassy materials in Bronze and Iron Age Italy? New data and general overview. Archaeological and Anthropological Sciences, 11, 1813-1841.

Dafalla, H. (1975). The Nubian Exodus. C. Hurst \& Company.

Daszkiewicz, M., \& Lahitte, M. (2013). Possibilities and limitations of using PXRF for analysis of ancient beads: An example from Gala Abu Ahmed, Sudan. In A. Hauptmann, O. Mecking, \& M. Prange (Eds.), Archäometrie und Denkmalpflege 2013. Jahrestagung an der BauhausUniversität Weimar. METALLA, 6, 269-273.

Dussubieux, L. (2009). Compositional analysis of ancient glass fragments from North Sumatra, Indonesia. In D. Perret \& H. Surachman (Eds.), Histoire de Barus III: Regards sur une place marchande de l'océan Indien, XIIe-milieu du XVIIe s (pp. 385-417). Association Archipel/EFEO.

Dussubieux, L., Cloquet, C., \& Pryce, T. O. (2021). Isotope analysis and its applications to the study of ancient Indian glass. In A. K. Kanungo, and L. Dussubieux (Eds.), Ancient glass of South Asia: Archaeology, ethnography and global connection (pp. 175-202). Springer Nature and IIT Gandhinagar. https://doi.org/10.1007/ 978-981-16-3656-1_6

Dussubieux, L., \& Gratuze, B. (2013). Glass in South Asia. In K. Janssens (Ed.), Modern methods for analysing archaeological and historic glass (pp. 399-413). Wiley and Sons.

Dussubieux, L., Gratuze, B., \& Blet-Lemarquand, M. (2010). Mineral soda alumina glass: Occurrence and meaning. Journal of Archaeological Science, 37, 1645-1655.

Dussubieux, L., \& Kanungo, A. K. (2013). Trace analysis of glass from Kopia. In A. K. Kanungo (Ed.), Glass in Ancient India: Excavations at Kopia (pp. 360-366). KCHR.

Dussubieux, L., Kusimba, C. M., Gogte, V., Kusimba, S. B., Gratuze, B., \& Oka, R. (2008). The trading of ancient glass beads: New analytical data from South Asian and East African soda-alumina glass beads. Archaeometry, 50(5), 797-821.

Dussubieux, L. \& Wood, M. (2021). Indian glass: Chronology and distribution in Eastern Africa. In A.K. Kanungo \& L. Dussubieux (Eds.), Ancient Glass of South Asia - Archaeology, ethnography and global Connection (pp. 511-532). Springer Nature / IIT Gandhinagar. https://doi.org/10. 1007/978-981-16-3656-1_21.

Emery, W. B., \& Kirwan, L. P. (1938). The royal tombs of Ballana and Qustul. Government Press. 
Fisher, M. M. (2012). The history of Nubia. In M. M. Fisher, P. Lacovara, S. Ikram, \& S. H. D'Auria (Eds.), Ancient Nubia: African kingdoms on the Nile (pp. 10-44). American University in Cairo Press.

Francis, P. Jr. (2002). Asia's maritime bead trade 300 BC to the present. University of Hawai'i Press.

Francis, P., Jr. (2007). Personal adornments. In S. E. Sidebotham \& W. Z. Wendrich (Eds.), Berenike 1999/2000: Report on the excavations at Berenike, including excavations in Wadi Kalalat and Siket, and the survey of the Mons Smaragdus Region (pp. 251-257). Cotsen Institute of Archaeology.

Gratuze, B. (2009). Les premier Verres au Natron retrouve's en Europe Occidentale: composition chimique et chronotypologie. In K. Janssens, P. Degryse, P. Cosyns, J. Caen, L. Van't Dack (Eds.). Annales du 17eme Congres de $l$ Association Internationale pour l'Histoire du Verre (pp. 8-14). AIHV, Antwerp.

Gratuze, B., Soulier, I., Barrandon, J. N., \& Royet, D. (1992). De l'origine du cobalt dans les verres. Revue D’archéométrie, 16(1), 97-108. https://doi.org/10.3406/ arsci.1992.895

Gratuze, B., Pactat, I., \& Schibille, N. (2018). Changes in the signature of cobalt colorants in Late Antique and Early Islamic glass production. Minerals, 8(6), 225. https://doi. org/10.3390/min 8060225

Hafsaas, H. (2006). Cattle pastoralists in a multicultural setting: The C-Group people in Lower Nubia 2500-1500 $B C E$. Bergen University Press/Birzeit University Press.

Henderson, J. (2013). Ancient glass: An interdisciplinary exploration. Cambridge University Press.

Henderson, J., Chenery, S., Faber, E., \& Kröger, J. (2016). The use of electron probe microanalysis and laser ablationinductively coupled plasma-mass spectrometry for the investigation of 8th-14th century plant ash glasses from the Middle East. Microchemical Journal, 128, 134-152.

Hodgkinson, A.K, Bertram, M. (2020). Working with fire: Making glass beads at Amarna using methods from metallurgical scenes. Journal of Archaeological Science: Reports, 33, https://doi.org/10.1016/j.jasrep.2020.102488.

Ignatiadou, D. (2000). Three cast-glass vessels from a Macedonian tomb in Pydna. Annales du 17eme Congres de l'Association Internationale pour l'Histoire du Verre (pp. 35-38). AIHV, Venice-Milan.

Kucharczyk, R. (2011). Glass from area F on Kom el-Dikka (Alexandria): Excavations 2008. Polish Archaeology in the Mediterranean, 20, 56-69.

Lankton, J. W., \& Dussubieux, L. (2006). Early glass in Asian maritime trade: A review and an interpretation of compositional analyses. Journal of Glass Studies, 48, 121-144.

McIntosh, S. K., Wood, M., Dussubieux, L., Robertshaw, P., Insoll, T., \& Cissé, M. (2020). Glass beads from Medieval Gao (Mali): New analytical data on chronology, sources, and trade. Journal of African Archaeology, 18, https://doi. org/10.1163/21915784-20200009.

Mirti, P., Pace, M., Malandrino, M., \& Negro Ponzi, M. (2009). Sasanian glass from Veh Ardasir: New evidences by ICP-MS analysis. Journal of Archaeological Science, 39, 1061-1069.

Mirti, P., Pace, M., Negro Ponzi, M. M., \& Aceto, M. (2008). ICP-MS analysis of glass fragments of Parthian and
Sasanian epoch from Seleucia and Veh Ardashir (Central Iraq). Archaeometry, 50, 429-450.

Molina, G., Odin, G. P., Pradell, T., Shortland, A. J., \& Tite, M. S. (2014). Production technology and replication of lead antimonate yellow glass from New Kingdom Egypt and the Roman Empire. Journal of Archaeological Science, 41, 171-184. https://doi.org/10.1016/j.jas.2013.07.030

Nenna, M.-D., \& Gratuze, B. (2009). Étude diachronique des compositions de verres employés dans les vases mosaïques antiques: résultats préliminaires. In K. Janssens, P. Degryse, P. Cosyns, J. Caen, \& L. Van't dack (Eds), Annales du 17e Congrès de l'Association internationale pour l'histoire du verre (pp. 199-205). University Press Antwerp.

Neri, E., Gratuze, B., \& Schibillle, N. (2019). The trade of glass beads in early medieval Illyricum: Towards an Islamic monopoly. Archaeological and Anthropological Sciences, 11, 1107-1122. https://doi.org/10.1007/ s12520-017-0583-5

Obłuski, A. (2013). Dodekaschoinos in Late Antiquity: Ethnic Blemmyes vs. Political Blemmyes and the arrival of Nobades. Der Antike Sudan, Mitteilungen der Sudanarchäologischen Gesellschaft zu Berlin e.V., 24, 144-147.

Obłuski, A. (2014). The rise of Nobadia: Social changes in Northern Nubia in Late Antiquity. Journal of Juristic Papyrology supplements, 20. Journal of Juristic Papyrology, Warsaw.

Osman, A. M. S. (1992). Nationalist archaeology: The case of the Sudan. In C. Bonnet (Ed.), Études Nubiennes: Conférence de Genève: Actes du VIIe Congrès international d'études nubiennes 3-8 septembre 1990 (pp. 225-236). Satigny Société Internationale d'Etudes Nubiennes.

Panighello, S., Orsega, E. F., van Elteren, J. T., \& Šelih, V. S. (2012). Analysis of polychrome Iron Age glass vessels from Mediterranean I, II and III groups by LA-ICP-MS. Journal of Archaeological Science, 39(2), 2945-2955. https://doi.org/10.1016/j.jas.2012.04.043

Phelps, M. (2016). An investigation into technological change and organisational developments in glass production between the Byzantine and Early Islamic Periods (7th12th centuries) focusing on evidence from Israel. Ph.D. thesis, University College, London.

Phelps, M., Freeston, I. C., Gorin-Rosen, Y., \& Gratuze, B. (2016). Natron glass production and supply in the late antique and early medieval Near East: The effect of the Byzantine-Islamic transition. Journal of Archaeological Science, 75, 57-71. https://doi.org/10.1016/j.jas.2016.08. 006

Pion, C., \& Gratuze, B. (2016). Indo-Pacific glass beads from the Indian subcontinent in early Merovingian graves (5th6th century AD). Archaeological Research in Asia, 6, 51-64. https://doi.org/10.1016/j.ara.2016.02.005

Poulain, D., Scuillier, C., \& Gratuze, B. (2013). La parure en verre et en ambre de la nécropole mérovingienne de Saint-Laurent-des-Hommes (Dordogne). Bulletin De L'association Française Pour L'archéologie Du Verre, 2013, 72-79.

Rehren, Th., \& Pusch, E. B. (2005). Late Bronze Age glass production at Qantir-Piramesses, Egypt. Science, 308(5729), 1756-1758. 
Rodziewicz, M. (1984). Les habitations romaines tardives d'Alexandrie: à la lumière des fouilles polonaises à Kôm el-Dikka [Alexandrie 3]. Éditions Scientifiques de Pologne, Warsaw.

Sarathi, A., Walz, J., \& Dussubieux, L. (forthcoming). Glass beads at Unguja Ukuu in the Late 1st millennium CE: Results of the 2018 Excavation in Zanzibar. In L. Dussubieux, \& H. Walder (Eds.), Glass bead technology, chronology, and exchange - LA-ICP-MS glass compositions from the Field Museum's Elemental Analysis Facility. Studies in Archaeological Sciences series. University of Leuven Press.

Schibille, N., Meek, A., Wypyski, M. T., Kröger, J., RosserOwen, M., \& Wade Haddon, R. (2018). The glass walls of Samarra (Iraq): Ninth-century Abbasid glass production and imports. PLOS ONE, 13(8), e0201749. https://doi.org/ 10.1371/journal.pone.0201749

Schibille, N., Gratuze, B., Ollivier, E., \& Blondeau, É. (2019). Chronology of early Islamic glass compositions from Egypt. Journal of Archaeological Science, 104, 10-18.

Schlick-Nolte, B., \& Werthmann, R. (2003). Glass vessels from the burial of Nesikhons. Journal of Glass Studies, 45, $11-34$.

Shinnie, P. L., \& Shinnie, M. (1978). Debeira West, a mediaeval Nubian town. Aris \& Phillips.

Shortland, A. J. (2002). The use and origin of antimonate colorants in early Egyptian glass. Archaeomtery, 44(4), 517530. https://doi.org/10.1111/1475-4754.t01-1-00083

Shortland, A. J., \& Eremin, K. (2006). The analysis of second millenium glass from Egypt and Mesopotamia, Part 1: New WDS analyses. Archaeometry, 48(4), 581-603.

Shortland, A. J., Kirk, S., Eremin, K., Degryse, P., \& Walton, M. (2018). The analysis of Late Bronze Age glass from Nuzi and the question of the origin of glass-making. Archaeometry, 60(4), 764-783.

Shortland, A., Schachner, L., Freestone, I., \& Tite, M. (2006). Natron as a flux in the early vitreous materials industry: Sources, beginnings and reasons for decline. Journal of Archaeological Science, 33(4), 521-530. https://doi.org/ 10.1016/j.jas.2005.09.011

Shortland, A., Rogers, N., \& Eremin, K. (2007). Trace element discriminants between Egyptian and Mesopotamian Late Bronze Age glasses. Journal of Archaeological Science, 34(5), 781-789.

Smirniou, M., \& Rehren, Th. (2011). Direct evidence of primary glass production in Late Bronze Age Amarna, Egypt. Archaeometry, 53(1), 58-80.

Spaer, M. (2001). Ancient glass in the Israel Museum: Beads and other small objects. Israel Museum, Jerusalem.

Taha, S. (2013). Attachment to abandoned heritage: The case of Suakin. BAR International Series S2477. Archaeopress.

Taha, S. (2021). Mega developments in Africa: Lessons from the Meroe Dam. In B. Britt \& M. L. S. Sørensen (Eds.), African heritage challenges (pp. 127-155). Palgrave Macmillan.

Then-Obłuska, J. (2015a). Cross-cultural bead encounters at the Red Sea port site of Berenike, Egypt: Preliminary assessment (Seasons 2009-2012). Polish Archaeology in Mediterranean Research, 24(1), 735-778.
Then-Obłuska, J. (2015b). Beads and pendants from Sedeinga, Nubia. BEADS. The Journal of the Society of Bead Researchers, 27, 29-45.

Then-Obłuska, J. (2016). Meroitic beadwork: An overview based on finds from Saï in acient Nubia. Polish Archaeology in Mediterranean Research, 25, 691-724.

Then-Obłuska, J. (2017a). Between the Nile and the Ocean: The bead assemblage from Shenshef in the Eastern Desert (4th-6th centuries AD). Polish Archaeology in the Mediterranean, 26(1), 725-752. https://doi.org/10.5604/01. 3001.0012 .1816

Then-Obłuska, J. (2017b). Beads and pendants in the late Harbor Temple and the harbor temenos of the Red Sea port of Berenike (seasons 2010-2013): Materials, techniques, functions and cultural attribution. Polish Archaeology in the Mediterranean, 26(2), 193-212. https://doi.org/10. 5604/01.3001.0012.1826

Then-Obłuska, J. (2018a). Beads and pendants from the Hellenistic to early Byzantine Red Sea port of Berenike, Egypt: Seasons 2014 and 2015. Polish Archaeology in the Mediterranean, 27(1), 203-233. https://doi.org/10.5604/ 01.3001.0013.2001

Then-Obłuska, J. (2018b). Short and long distance contacts of Late Antique Nubia: A view through the bead hole. In M. Honegger (Ed.), Nubian archaeology in the XXIst century: Proceedings of the Thirteenth International Conference for Nubian Studies, Neuchâtel, 1st-6th September 2014 [=Orientalia lovaniensia analecta 273] (pp. 587-595). Peeters.

Then-Obłuska, J., (2019). Bead trade in Roman Ports: A view from the Red Sea port of Marsa Nakari. In A. Manzo, C. Zazzaro, \& D. J. De Falco (Eds.) Stories of globalisation: The Red Sea and the Persian Gulf from Late Prehistory to Early Modernity. Selected Papers of Red Sea Project VII (pp. 264-80). BRILL.

Then-Obłuska, J. (2021). Indian Glass Beads in Northeast Africa between the first and sixth centuries CE. In A.K. Kanungo and L. Dussubieux (Eds.), Ancient glass of South Asia - archaeology, ethnography and global connection (pp. 533-557). Springer Nature / IIT Gandhinagar. https://doi.org/10.1007/978-981-16-3656-1_22

Then-Obłuska, J. (forthcoming). Beads from excavations at Qustul, Ballana, Adindan, Serra East, and Dorginarti, Part 1: A-Group, Post-A-Group, C-Group, Pan Grave, Kerma, Middle Kingdom, and New Kingdom Beads. The University of Chicago Oriental Institute Nubian Expedition Volume 16. Oriental Institute University of Chicago Press.

Then-Obłuska, J., \& Dussubieux, L. (2016). Glass bead trade in the Early Roman and Mamluk Quseir ports: A view from the Oriental Institute Museum assemblage. Archaeological Research in Asia, 6, 81-103.

Then-Obłuska, J., \& Dussubieux, L. (2021). Beads for the nomads of Late Antiquity: Chemical characterization of glass from the Blemmyan tumuli at Kalabsha, Nubia, of the mid-fourth century CE. Archaeometry, 63(6), 12551271. https://doi.org/10.1111/arcm. 12680

Then-Obłuska, J., \& Wagner, B. (2019a). Glass beads and pendants from Meroitic and Nobadian Lower Nubia, Sudan: Chemical compositional analysis using laser ablation-inductively coupled plasma-mass spectrometry. 
Archaeometry, 61(4), 856-873. https://doi.org/10.1111/ arcm.12465

Then-Obłuska, J., \& Wagner, B. (2019b). Glass bead trade in Northeast Africa. The evidence from Meroitic and postMeroitic Nubia, PAM Monograph Series 10. University of Warsaw Press. DOI: https://doi.org/10.31338/uw.97883 23539070

Tite, M. S., \& Shortland, A. J. (2003). Production technology for copper-and cobalt-blue vitreous materials from the New Kingdom site of Amarna: A reappraisal. Archaeometry, 2, 285-312.

Tite, M., Pradell, T., \& Shortland, A. (2008). Discovery, production and use of tin-based opacifiers in glasses, enamels and glazes from the Late Iron Age onwards: A reassessment. Archaeometry, 50(1), 67-84.

Turner, W. E. S., \& Rooksby, H. P. (1959). A study of opalising agents in ancient opal glasses throughout three thousand four hundred years. Glastechnische Berichte, $32 K(7)$, $17-28$.

Török, L. (2008). Between two worlds: The frontier region between Ancient Nubia and Egypt 3700 BC - 500 AD. BRILL.

Van Strydonck, M., Gratuze, B., Rolland, J., \& De Mulder, G. (2018). An archaeometric study of some pre-Roman glass beads from Son Mas (Mallorca, Spain). Journal of Archaeological Science: Reports, 17, 491-499.

Wedepohl, K. H., Simon, K., \& Kronz, A. (2011). Data on 61 chemical elements for the characterization of three major glass compositions in late antiquity and the middle ages. Archaeometry, 53, 81-102.

Welsby, D. (1996). The kingdom of Kush. Markus Wiener Publishers.

Welsby, D. (2002). The Medieval Kingdoms of Nubia: Pagans. British Museum Press.

Williams, B. B. (1983). Excavations between Abu Simbel and the Sudan Frontier, Keith C. Seele, Director. Part 5: C-Group, Pan Grave, and Kerma Remains at Adindan Cemeteries $T, K, U$, and $J$. The University of Chicago Oriental Institute Nubian Expedition, OINE 5.

Williams, B. B. (1986). Excavations between Abu Simbel and the Sudan Frontier, Keith C. Seele, Director. Part 1: The A-Group Royal Cemetery at Qustul, Cemetery L. The University of Chicago Oriental Institute Nubian Expedition, OINE 3 .

Williams, B. B. (1989). Excavations between Abu Simbel and the Sudan Frontier, Keith C. Seele, Director. Parts 2, 3, and 4: Neolithic, A-Group, and Post-A-Group Remains from Cemeteries $W, V, S, Q, T$, and a Cave East of Cemetery $K$. The University of Chicago Oriental Institute Nubian Expedition, OINE 4.
Williams, B. B. (1990). Excavations between Abu Simbel and the Sudan Frontier, Part 7: Twenty-Fifth Dynasty and Napatan remains at Qustul Cemeteries $W$ and $V(\mathrm{p}$. 7). The University of Chicago Oriental Institute Nubian Expedition.

Williams, B. B. (1991). Excavations Between Abu Simbel and the Sudan Frontier, Part 9: Noubadian X-Group Remains from Royal Complexes in Cemeteries $Q$ and 219 and Private Cemeteries $Q, R, V, W, B, J$, and $M$ at Qustul and Ballana (p. 9). The University of Chicago Oriental Institute Nubian Expedition.

Williams, B. B. (1992). Excavations Between Abu Simbel and the Sudan Frontier, Part 6: New Kingdom Remains from Cemeteries $R, V, S$, and $W$ at Qustul and Cemetery $K$ at Adindan (p. 6). The University of Chicago Oriental Institute Nubian Expedition.

Williams, B. B. (1993). Excavations at Serra East, Parts 1-5: A-Group, C-Group, Pan Grave, New Kingdom, and $X$-Group Remains from Cemeteries $A-G$ and Rock Shelters (p. 10). The University of Chicago Oriental Institute Nubian Expedition.

Williams, B. B. (2009). Rescue and Loss as Themes of the Oriental Institute Nubian Expedition Experience in the High Dam Archaeological Salvage Campaign. A paper given at the 2009 conference in Aswan on the 50th anniversary of the appeal to rescue the archaeology of Nubia. https:// www.academia.edu/36854796/Rescue_and_Loss_as_ Themes_of_the_Oriental_Institute_Nubian_Expedition_ Experience_in_the_High_Dam_Archaeological_Salvage_ Campaign.

Williams, B. B., \& Heidorn, L. (2019). The OI and Nubia. In Discovering New Pasts: The OI at 100 (pp. 358-387). The Oriental Institute of the University of Chicago.

Wood, M., Panighello, S., Orsega, E. F., Robertshaw, P., van Elteren, J. T., Crowther, A., Horton, M., \& Boivin, N. (2017). Zanzibar and Indian Ocean trade in the first millennium CE: The glass bead evidence. Archaeological and Anthropological Sciences, 9, 879-901.

Wood, M. (2019). Glass beads and trade in the Western Indian Ocean. Oxford University Press. https://doi.org/10.1093/ acrefore/9780190277727.013.334

Publisher's Note Springer Nature remains neutral with regard to jurisdictional claims in published maps and institutional affiliations. 